\title{
THE IMPACT OF WORKING CAPITAL MANAGEMENT ON THE PERFORMANCE OF LISTED FIRMS: EVIDENCE OF AN EMERGING ECONOMY
}

\author{
Ronald Ebenezer Essel1 ${ }^{1}$, , Joyce Akua Brobbey ${ }^{1}$ \\ 1 University of Cape Coast (UCC), College of Distance Education (CoDE), Unit of Business Programmes, Cape Coast, Ghana, West Africa.
}

ABSTRACT - The purpose of this scientific inquiry is to empirically examine the impact of working capital management (WCM) on firm performance (FP) in the context of an emerging economy, Ghana. The research utilized a dynamic panel System of Generalized Method of Moment (GMM) i.e., Blundell and Bond 1998 estimator to test the hypotheses. Utilizing financial data extracted from the final accounts of all the 36 companies listed on the Ghana Stock Exchange (GSE), spanning 2010-2019, the study examined WCM-FP nexuses by following the methodologies of researchers in extant literature. Results indicates that, whilst number of days inventory, number of days account receivables and financial leverage demonstrated negative associations with $\mathrm{FP}$, number of days account payables, sales growth, firm size, current ratio, fixed financial assets to total assets ratio depicted positive associations with FP. Cash Conversion Cycle, however, exhibited a quadratic concave relationship with return on assets, an indication that, there exist an optimal WCM level that maximizes FP and as such, corporate financial managers are entreated to operate within the boundaries of this optimal WCM range to maximize profitability.
ARTICLE HISTORY

Received: $1-10-2021$

Revised: 29-10-2021

Accepted: 26-11-2021

\section{KEYWORDS}

Emerging Economy

Ghana

Performance

Profitability

Working Capital

Management

\section{INTRODUCTION}

The financial predicament of the 2007-2009 era, which led to the collapse of many giant companies around the globe, have drawn the attention of corporate financial managers to focus more on efficient management of organizational resources, especially the management of assets with a one-year maturity period (Mielcarz et al., 2018). This is the focal concern of WCM, also referred to as short term financial planning, due to the fact that, it deals with the management of the firm's short-term financing needs/requirement i.e., the management of current assets (CA) and current liabilities (CL) and the interrelations between them (Ross, Westerfield and Jaffe, 2016). In the finance literature, WCM is one of the key decisions financial managers take, alongside capital budgeting (investment decisions), capital structure (financing decisions) and dividend policy decisions (Ross, Westerfield and Jaffe, 2016).

WC also referred to as net working capital (NWC) or business capital or operational capital (Lamptey et al., 2017) is the resource/funds/capital set aside for the smooth running of the day-to-day operations of organizations (representing the operating liquidity of firms) such that businesses always have adequate funds to meet short term recurrent liabilities as and when they fall due in full and on time. WC is considered as the life-giving power of business entities, management of which is viewed as a highly imperative role of financial management (Afrifa, 2013). WC is the most critical element when it comes to the maintenance of liquidity, solvency, survival and profitability of businesses. Mathematically, WC is defined as CA [made up of cash and cash equivalent, account receivable, inventory] minus CL [including account payable, overdraft and other short-term liabilities]. WC constituents include AR, AP, INV and CCC to evaluate the efficacy of a business' WCM vis-à-vis specific liquidity metrics (Costa, 2014).

Extant literature on WCM have produced varied perspectives on the effectiveness of WCM as a mechanism for enhancing FP. Whilst one scholarly school of thought is of the view that, raising the investment in WC particularly in stocks, could result in increased sales, others contend that, securing the prices of inventory to ensure a lower procurement cost is paramount (Corsten \& Gruen, 2004).

It is thus highly imperative to comprehend the dynamics, particularly how reducing or increasing WC to its optimal levels will result in enhancing firm's operational efficiency with the overall effect reflecting in improved company market value (Aktas et al., 2015). Extant literature largely supports the assertion that, efficient WCM positively influence FP (Qurashi \& Zahoor, 2017; Abdullah, \& Siddiqui, 2019; Sattar, 2019). The efficient management of WC could result in firms freeing up cash that could have been lock-up/tied-up and would minimize the need for external financing and then utilize these external funds for expansion purposes when the need arises (Braimah et al., 2021).

The main objective of every business-oriented firm is to maximize shareholders wealth via increasing share price. This can be achieved through profit maximization. However, in quest of this objective, the firm needs to maintain sufficient operational liquidity in order to be in a position to finance its daily operational activities. A crucial assignment for corporate finance executives/administrators is to attempt to strike a trade-off between profitability and liquidity such that in pursuit of short-term profitability, liquidity is not compromised as this could result in long term insolvency (Hussain et al., 2021). Managing a firm's WC efficiently is the status quo for contemporary organizations to remain 
competitive, maximize operational efficiency, enhance earnings and profitability and guarantee corporate survival in today's competitive global economy (Peng and Zhou, 2019). Inefficient WCM trends have resulted in academics/researchers/scholars to come out with quality and efficient models adequately robust to test liquidity levels of firms (Song et al., 2019). WCM is very important because it forms a substantial part of the business' total assets (Asiedu et al., 2020), impact positively on firm's earnings/profitability, (Braimah et al., 2021), aids in minimizing business risk and play a vital part in maximizing shareholder's wealth (Bhatia \& Srivastava, 2016).

For businesses to achieve efficient WCM, firm's CCC otherwise known as cash operating cycle or working capital cycle, defined as the number of days between settling debt owed suppliers and collecting cash from sales, must be as short as possible. In other words, as much as possible, firms must ensure that, the time lag for settling accounts payable must be comparatively longer than the time it takes to collect account receivable that arise as a result of credit extension made to dependable customers for final goods sold. This would ensure solid liquidity positions for firms at all times (Ukaegbu, 2014). Put differently, with respect to the buying and selling of inventory, the CCC which is equivalent to INV plus AR minus AP is a sophisticated model, where it takes time, for firms to collect funds from account receivable and to make payment to account payable (Tsagem, 2020).

When stock levels are low, maintaining a positive WC becomes an uphill task. As Mazzarol and Rebound (2020) opine, the costs forgone in respect of maintaining a positive WC could result in a decline in gross profit. As such, to maintain a good equilibrium with respect to profitability and liquidity, there is the need to make efficient investment in working capital (Hamza et al., 2015). There are two main approaches or policies in financing WC, namely aggressive and consecutive. Adopting an aggressive WCM approach, implying operating with very low CA or high CL, could result in loss of sales and customer loyalty or goodwill in the event of sales increases, as the firm will not be in the position to meet customer's sale demand. In addition, a drastic decline in credit extension may trigger a corresponding reduction in sales level in view of the adoption of the aggressive WC policy or approach ( $\mathrm{Ng}$ et al., 1999; Wilner, 2000).

Conversely, adopting a conservative WCM policy, implying injecting more resources in WC or operating with low CL, may increase sales, improve relationships with clients, entice clients who prefer buying on credit, and improve overall profitability due to the fact that the cost of possible sales interruption and clientele loss is minimal (Garcia-Teruel and Martinez-Solano, 2007; Altaf \& Shah, 2018). Nevertheless, there is the opportunity cost in so far as, sales decline and funds are lock-up in inventory, possibility of bad debt (Dary \& James, 2019), increased cost of administering account receivable (Abuhommous, 2017), increased carrying cost, possibility of obsolescence, among others. Irrespective of the approach utilized, associated cost and benefits exist. In the face of these quandaries, both theory and practice have not been able to answer the question as to which of the two approaches or policies is superior. Therefore, executives and administrators who end up selecting the optimal WCM policy will laugh last, as this will results in value-creation for firm and shareholders (Braimah et al., 2021). WCM-performance-connexion has been and continue to be a subject of strong academic and scholarly research interest (Ukaegbu, 2014; Braimah et al., 2021).

A number of studies have been conducted to explore the association between WCM and FP in Ghana. In as much as the additions of these authors cannot be swept under the carpet, an assessment of the present state of WCM mechanisms is highly vital to capture the newest happenings in this very important facet of business operations in Ghana. This information or knowledge will aid appraise policies, practices, and upcoming literature on WCM within the Ghanaian context. The present crop of scientific inquiries on the association between WCM and FP is aimed at providing managerial information as to the right combination of CA-CL which yields the utmost profitability for businesses and at the same time reduce risk to the minimum (Makori \& Jajongo, 2013). Notwithstanding, the above, there appears to be limited research conducted on the subject matter, which is an astounding gap in extant literature (Hamza et al., 2015; Asiedu et al., 2020; Braimah et al., 2021). Again, careful scrutiny of the studies conducted on the association between WCM and FP in Ghana reveals that, most of the researchers, concentrated their analysis on a particular sector or industry.

For instance researchers such as Tauringana \& Afrifa (2013), Hamza et al. (2015), Donkor (2015), Attom (2016), Lamptey et al. (2017), Afrifa et al. (2018), Lamptey et al. (2020), (Braimah et al. (2021) focused their attention on the SME sector; Akoto et al. (2013), Korankye \& Adarquah (2013), Adam et al. (2017), Pempeh (2018), Adam and Quansah (2019), Akomeah et al. (2019), Amponsah and Asiamah (2020), Asiedu et al. (2020), Yakubu et al. (2020) concentrated on the manufacturing sector; Yeboah \& Agyei (2012), Agyei et al. (2013)on the Banking sector; Frimpong (2018), Obeng et al. (2021) on Non-financial firms; Yakubu et al. (2017), Yakubu (2021) on Listed non-financial firms (LNFFs).

To the best of the author's knowledge, none of the researches conducted on the association between WCM and FP in Ghana utilized data on the entire firms listed on the Ghana Stock Exchange (GSE).

The closest studies on the relationship between WCM and FP in Ghana, that utilized data on all listed firms on the GSE, are the following: the study conducted by Isshaq and Bokpin (2009) in which they assessed corporate liquidity management of listed firms on the GSE with the objective of establishing the determinants of corporate liquidity holdings; the study conducted by Nyeadi et al. (2018), which examined the determining factors of WC needs of 28 out of the 36 listed companies on the GSE. The idea in this current inquiry, is to assess the performance of the entire Ghanaian capital market with respect WCM. This inquiry is therefore motivated by this observable lacuna. The purpose of this present study is therefore to empirically examine the effect of WCM on the performance of all 36 listed companies on the GSE as contributing research to address this observable gap in the literature. The focal research question for this study is as follows:

1) Is the performance of listed firms in Ghana influenced/affected by WCM mechanisms? Put differently,

2) To what extent does WCM impact FP of listed firms in Ghana? 
The remaining part of this manuscript is organized as follows: The second section is a review of related literature and hypotheses development. The third section is research methodology. The fourth section is results and discussion. The fifth section is the conclusion and recommendations.

\section{RELATED WORK}

\section{Empirical literature}

The numerous empirical inquiries conducted to assess the association between WCM and FP in various markets have yielded varied, heterogeneous and inconclusive results. This can be attributed to the utilization of wide-ranging WC measurement variables such as AR, AP, INV and CCC (Yakubu, 2021) combined with varied control variables such as SIZE, GROW, LEV, FFA, variability of net operating income, GDP growth, diverse liquidity measurement metrics etc. (Alrahamneh, Chu and Hong, 2020) with different mediating or moderating variables, all dependent on the author's interest, the operating market of interest, country-specific effects, methodological estimation approaches as well as the employment of diverse performance measurement metrics both accounting and market-value performance measures, since performance is reliant on the effectiveness of the whole WCM structure and not on individual mechanisms (Ofoeda, 2017; Abdul Razak \& Amin, 2020).

Whereas Onwumere et al. (2012), Mwangi et al., 2014; Abuhommous, 2017 and Dary \& James, 2019 argue that aggressive WC injection approach yield direct association with performance via profitability, there are numerous researches that support the view that conservative WC injection approach substantially improve performance via profitability (Garcia-Teruel and Martinez-Solano, 2007; Mohamad and Saad, 2010 and Altaf \& Shah, 2018). With respect to WC financing, Onwumere et al. (2012) and Mwangi et al. (2014) suggest that, aggressive WC funding approach results in superior improvement in profitability whilst Garcia-Teruel and Martinez-Solano, 2007; Mohamad and Saad, 2010 and Altaf \& Shah, 2018 opine that conservative WC funding approach enhances profitability and value of shareholders. Ogundipe et al. (2012) as well as Pirashanthini et al. (2013) established no statistically significant association between WC injection and funding approaches with profitability in Nigeria and Sri Lanka, respectively.

Anton and Nucu (2021) investigated the association between working capital and firm profitability for a sample of 719 Polish listed firms, spanning 2007-2016. By employing a quantitative approach utilizing varied panel data approaches i.e., ordinary least squares, fixed effects, and panel-corrected standard errors models, the study revealed a quadratic relationship between working capital level and firm profitability, implying that working capital has a direct impact on the profitability of Polish firms to a break-even point i.e., optimum level and thereafter, working capital starts to negatively impact firm profitability.

Senan et al. (2021) assessed how Indian commercial banks' performance can be enhanced via WCM determinants. By employing static models GMM, pooled, fixed and random effects models, and utilizing a balanced panel dataset for 98 Indian banks spanning 2008-2018, the results showed that net profit margin, profit after tax, monetary policy, and working capital cycle are the most important working capital factors that impact Indian commercial banks' performance measured by ROA. Moreover, among the working capital, the results showed that current ratio, assets size, net profit margin ratio, and return on capital employees have significant positive effects on ROE.

Alvarez, Sensini and Vazquez (2021) examined the effect of WCM on the profitability proxies by ROA and ROE of 177 SMEs operating within the manufacturing sector of Argentine. Employing multivariate regression model via FE, the study revealed, significantly positive relationships between all components of working capital i.e., INV, AR, AP and CCC and profitability, suggesting that an increase in each variable considered determines an improvement in FP. Contrariwise, financial leverage showed significantly negative relationship with profitability, suggesting that an increase in debt yields a negative influence FP.

Othuon et al. (2021) evaluated the impact of WCM on FP of 41 small-scale coffee wet mills operating in Embu County, Eastern Kenya. Deploying panel data multivariate regression analysis for the period 2014-2018, the study depicted that the current ratio and average payment period negatively affected the return on small-scale coffee wet mills' assets. Thus, the wet mill processors could lower their payables period and current ratio to improve return on assets. The study revealed that the firm's Size and age also had a positive and negative effect, respectively, on return on assets of small-scale coffee wet mills. Both average payment period and current ratio had a positive effect on return to farmers. The study concluded that WCM constituent i.e., average payment period and current ratio, negatively influences ROA while positively influencing farmers and further recommended that, the management of the coffee wet mills should increase the current ratio and lengthen the average payment period to enhance return payable to farmers.

Owolabi and Halimah (2021) assessed the influence of WCM constituents on return on sales (ROS) of 12 selected manufacturing firms listed on the Nigeria Stock Exchange covering the period, 2009 - 2019. Utilizing panel data multiple regression analysis, the study revealed that inventory turnover (ITO) and average receivable period (ARP) had positive significant impact on ROS, implying that, a 1\% increase in ITO increases ROS by $0.56 \%$, and $1 \%$ increase in ARP increases ROS by $0.0190711 \%$. The study, therefore, concluded that working capital components such as ITO, ARP, CCC, and firm size have a significantly positive impact on ROS and ROA.

In a recent study, Braimah et al. (2021) assessed the influence of WCM on SMEs performance in Ghana, measuring performance via three profitability proxies namely, gross operating profit (GOP), net operating profit (NOP) and ROA. By using information on 336 SMEs, spanning 2007 - 2016 and using GMM econometric technique, their findings 
revealed the following: a direct association between AP and profitability; an indirect association between both INV and CCC and profitability; and an inverted U-shaped association between AR and profitability.

In another recent Ghanaian study, Obeng et al. (2021) researched to establish if effective WCM enhances firm profitability and firm value of LNFFs. Utilizing financial information from the annual reports of nineteen LNFFs, spanning 2009-2016, and using a dynamic panel system GMM, their study revealed no statistically significant association between WCM proxy by CCC and performance proxies by accounting profitability and market value; significant association statistically between WC policies and both market value and accounting profitability. The authors recommended that executive/administrators of LNFFs should implement an aggressive WC policy so as to create shareholder value.

Yakubu (2021) investigated the effect of WCM proxies by INV, AP, AR and CCC on dividend policy of LNFFs in Ghana. Using data spanning 2007-2016 and estimating via ordinary least squares (OLS), the study results showed a direct association between both CCC and INV and dividend policy. Further, the study findings depicted a direct association between both profitability and firm growth and dividend policy even though the relarelationship insignificant. The authors concluded that INV is an important element affecting the dividend policy decisions of firms in Ghana.

Yakubu et al. (2020) examined the determining factor of WCM of manufacturing firms listed on the GSE under innovative work behavior viewpoint, using the GMM on firm-level and macroeconomic data spanning 2007-2016. The authors found that a manufacturing firm's WCM is substantially moved by profitability, growth opportunities, operating cycle leverage, and SIZE. Conversely, firm age and GDP growth didn't affect WC needs. The study results bring fresh proofs for administrators/executives to comprehend the focal inside and outside factors impacting WC behavior in order to take decisive decisions with respect to the WC level to maintain effective operations.

Amponsah-Kwatiah and Asiamah (2020) assessed the impact of WCM on accounting profitability (proxies by ROA and ROE) of listed manufacturing firms in Ghana. Employing a quantitative-causal research approach and using a balanced panel data of twenty companies listed on the GSE, spanning 2015 - 2019, the study indicated that INV, AR, AP, CCC, CA, CR and SIZE have direct effects on ROA and ROE whilst LEV influenced them indirectly.

Asiedu et al. (2020) assessed WCM impact on FP proxy by ROE of manufacturing companies listed on GSE. Employing descriptive and referential analysis and using panel data of 13 firms covering 2010 - 2019, relying on financial data, the study depicted that INV had significant and indirect correlation with ROE whilst CCC had significant impact on ROE.

Lamptey et al. (2020) hypothesize overconfidence bias in WCM and performance of SMEs by employing qualitative case study investigation to gain insight into SME administrator's overconfident characteristics. The authors concluded that overconfidence bias can distract investment in WC with the likelihood of over investing in stock, assuming SME leadership have sufficient internal owner's funds with the hope of improving profitability.

Prempeh and Peprah-Amankona (2019) analyzed the association between WCM and the profitability of eleven listed manufacturing firms in Ghana, using a dynamic balanced panel estimation, covering 2011-2017. The inquiry showed that there was a statistically significant direct association between WCM and profitability.

Peprah and Riziki (2019) examined the association between WCM proxies by CR and cash ratio and profitability (proxy by ROA) of 25 Ghanaian Universal Banks from 2016-2018, using a panel data regression estimation technique. Results showed a slight statistically significant inverse/indirect association between WCM and profitability. The study corroborates the financial rule of thumb that WC is indirectly associated with profitability as more WC will force profitability downwards and vice versa.

Akomeah and Frimpong (2019) assessed the impact of WCM proxies by AR, AP, INV \& CCC on profitability proxy by GOP of seven manufacturing firms listed on the GSE. Using financial data extracted from the annual reports of the seven firms, spanning 2005-2014 and employing fixed effect (FE) panel data regression, the study revealed that AR and INV had a significant inverse influence on profitability whilst, AP had statistically insignificant direct impact on profitability. CCC, CR, and SIZE depicted significant direct effect on profitability.

Adam and Quansah (2019) investigated the impact of WCM policies on shareholder wealth formation for six listed manufacturing companies in Ghana, spanning 2000-2013 using firm's financial information and data from GSE publications. Employing a longitudinal explanatory non-experimental research approach, combined with dynamic panel Autoregressive Distributed Lags (ARDL) estimation technique, the authors disclosed that conservative CA investment policies raise economic value added (EVA), whilst aggressive CA investment policies enhanced market-to-book ratio and TQ in the long-run. Conversely, conservative CA funding policies improves market-to-book ratio, TQ, and EVA in the long run. Consequently, investors discount aggressive CA funding policies. The authors suggested that, companies following an aggressive CA investment policy should combine it with a conservative CA funding policy to generate wealth for shareholders

Agyeman et al. (2019) examined the effect of WCM on Global Haulage Company Limited (GHCL) profitability. By employing ARDL technique to assess the association between WCM and profitability of GHCL, covering 1995 - 2013 , the study's findings revealed that debt ratio, SIZE and CA to total asset's ratio are indirectly associated to profitability, whilst CL to total asset's ratio is directly related to profitability. The authors suggested that, managers should reduce their level of debt usage in their operations, in order to reduce the interest burden on debt and improve profitability. In addition, managers should consider implementing aggressive WC policies to enhance profitability.

Darkwah et al. (2019) explored the impact of WCM on profit deploying logistic regression (LR) and discriminant analysis (DA) on thirteen listed firms operating in the industrial/manufacturing sectors of Ghana, utilizing financial data from final accounts, spanning 2009 to 2014. Findings indicated that the LR of the prognostic variable i.e., Profit on the 
explanatory variables were statistically significant and that, there was no difference in variances for two firm categorizations. These findings suggest that, the linear discriminant model is efficient in discriminating between a firm which effectively managed its WC from one which did not.

Peprah et al. (2019) explored linkages between WC (proxies by CR, and cash ratio) and financial sustainability (FS) typified by self-support for chosen Christian denominations in Ghana. Employing bivariate correlation, the final accounts from 2013 to 2017 of fifteen members of the Ghanaian Christian Council were sampled via convenient sampling and the study showed the following results: there was a direct association between WC and FS among Christian denomination in Ghana; there was a slight direct statistically significant association between self-support and cash ratio; a big positive statistically significant association between self-support and CR. The authors suggested to Ghanaian churches to pursue an improving association between their WC and FS to avoid a likely church closure.

Frimpong (2018) assessed the impact of aggressive and conservative WC approaches on value creation, using financial information from ten LNFFs covering 2004-2015 and deploying quantitative research approach via panel cointegration and panel fully modified OLS (FMOLS) methodology. Findings revealed that there was a long-run equilibrium association between WC variables and shareholders' value creation. Findings from panel FMOLS shows that aggressive CA investment policies improved market-to-book ratio in the long-run. Similarly, conservative CA funding approach improved market-to-book ratio in the long-run.

Nyeadi et al. (2018) examined the determining factors of WC needs of twenty-eight listed companies on the GSE, covering the period 2007 to 2014, utilizing a dynamic panel system of GMM. Results indicated that WC in Ghanaian firms is determined by sales, profitability, age, growth, GDP growth, leverage and operating cycle. Further, the research revealed that, while age, profitability and operating cycle strongly influenced WC positively, GDP growth, sales growth and leverage had a negative association with WC. A cautious examination of the researches undertaken on the relationship between WCM and FP in Ghana reveals that, most of the empirical inquires, focused their investigations on a particular sector/industry of the economy say the SME sector, the manufacturing sector, the financial sector, non-financial firms, LNFFs among others. To the best of the author's knowledge, none of the researches conducted on the association between WCM and FP in Ghana utilized data on the entire firms listed on the GSE. This current empirical inquiry therefore assesses the influence of WCM on the performance of all 36 listed companies on the GSE as a contributing study to address this observable lacuna in the literature.

The following hypotheses are developed based on the extant related literature reviewed above on WCM and FP:

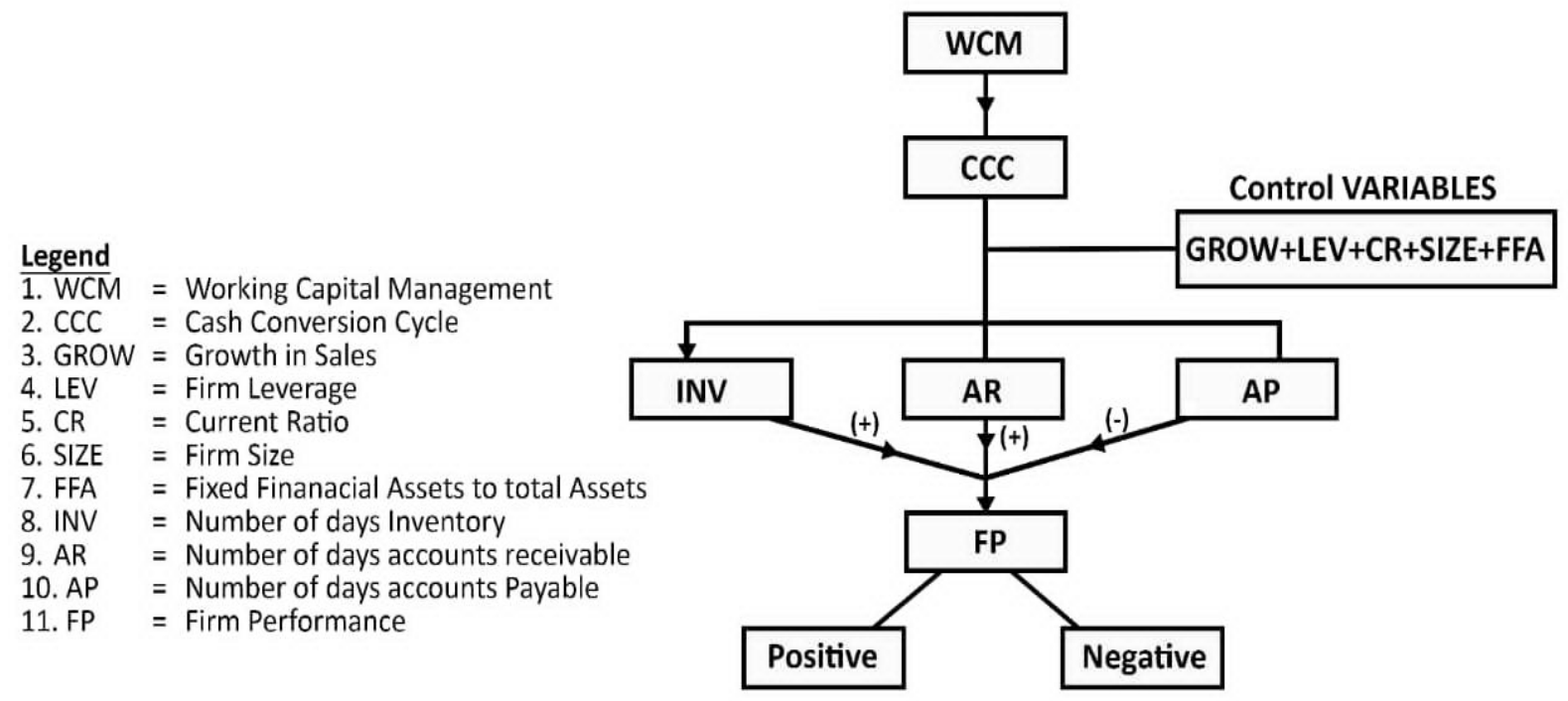

\section{Source: Authors Construct}

Figure 1. Conceptual / Theoretical Framework [Research Model] of the nexuses between Working Capital Management and Firm Performance.

The conceptual/theoretical framework [research model] displayed in figure 1 indicates that the constituent of WC/CCC i.e., INV, AR \& AP combined with its associated control variables i.e., GROW, LEV, CR, SIZE FFA could influence FP either positively or negatively as evident in the literature reviewed. 


\section{Hypotheses Development}

The following hypotheses are formulated based on theoretical grounding and related literature review.

H1: An indirect association exist between INV and FP. This hypothesis is theoretically supported, as low INV implies high stock turnover and increased sales, resulting in improved profitability. This is backed by empirical evidences such as Akomeah \& Frimpong (2019); Phuong and Hung (2020); Braimah et al. (2021) among others. $H_{2}$ : An indirect association exist between AR and FP. This hypothesis is theoretically supported, as low AR means, cash emanating from goods sold on credit are quickly collected, improving the firm's cash holding positions, resulting in high/improved profitability. This is backed by empirical evidences such as Kodithuwakku (2015); Kasozi (2017); Akomeah \& Frimpong (2019) among others.

H3: A direct association exist between AP and FP. This hypothesis is theoretically supported, as longer the number of days i.e., high values indicates that, the firm hold funds or cash meant for settling creditors for a longer period before paying their creditors. This improves the firm's cash holding position and results in improved profitability. This is backed by empirical evidences such as Rahman Iqbal and Nadeem (2019); Kasahun (2020); Braimah et al. (2021).

H4: An indirect association exist between CCC and FP. This hypothesis is theoretically supported, as shorter CCC periods i.e., number of days or low values imply excellent WCM or liquidity position, resulting in improved profitability. This is backed by empirical evidences such as Ray (2012); Ukaeba (2014); Nikkinen, Graham and Enavist (2014).

H5: A direct association exist between SIZE and FP. This hypothesis is theoretically supported as ceteris paribus, large, credit worthy, blue chip corporations perform better than their relatively smaller counterparts, as evident empirically in the works of Akoto, Awunyo-Vito and Angmor (2013); Akomeah and Frimpong (2019); Braimah et al. (2021).

H6: A direct association exist between GROW and FP. This hypothesis is theoretically supported, as the higher the growth in sales level, the higher the firm's profit margin and this is evidence empirically in the works of Akinlo (2012); Kasahun (2020); Braimah et al. (2021).

$H_{7}$ : An indirect association exist between LEV and FP. This hypothesis is theoretically supported, as highly leveraged or geared firms are faced with gargantuan borrowing cost i.e., huge interest on debt facilities which eats/erase substantial portions of firm's profits. This is backed by empirical evidences such as Ray (2012); Rahmman, Iqbal and Nadeem (2019); Kasahun (2020).

Hs: A direct association exist between CR and FP. This hypothesis is theoretically supported, as firms with $\mathrm{CR}>1$, have adequate $\mathrm{CA}$ to take care of their recurrent $\mathrm{CL}$ as and when they fall due, in full and on time, improving firm's liquidity positions and hence generating improved firm profitability. This is backed by empirical evidences such as Rahman, Iqbal and Nadeem (2019); Akomeah and Frimpong (2019); Braimah et al. (2021).

H9: A direct association exist between FFA and FP. This hypothesis is theoretically supported as firms with high FFA yields high profitability as evidenced empirically in the works of Abuzayed (2012); Asiedu et al. (2020).

\section{Firm Performance [FP]}

The criteria for performance measurement are reliant on the researcher's interest and the basis of justification. A cautious examination of extant literature reveals that scholars and researchers have measured FP using two key metrics namely, financial i.e., accounting or market-based performance measures including profitability, liquidity, efficiency, gearing, and market values indicators as well as non-financial measures including operational measures, quality measures, overall competitive position and customer satisfaction indicators. This is performed via either undertaking objective scrutiny of the company's annual reports or by collecting subjective information from survey respondents based on their individual opinions on FP. This current scientific inquiry measures FP via extracting financial information from the financial statements of all the 36 listed firms understudy, focusing on one key profitability measure i.e., return on assets (ROA), and one key market value indicator i.e., TQ.

\section{RESEARCH METHODOLOGY}

\section{Sample and Data}

This present inquiry utilized data collected from all 36 firms listed on the GSE, spanning 2010-2019, yielding a total of 324 balanced panel observations. The 36 listed firms cut across all industries/sectors of the Ghanaian economy, ranging from metal, mining \& oil, manufacturing \& trading, finance \& insurance services, Agric \& Agro Processing, Pharmacy \& Beverage to IT \& Paper conversion sectors as depicted in Table 1. The author's interest in this current study was to assess the performance of the entire Ghanaian capital market, which as at October 2021 lists 42 equities and 2 corporate bonds from 36 companies, with market capitalization of GHS64.62 billion as at $28^{\text {th }}$ October 2021. Currently, the types of stocks listed on the GSE are common stocks or ordinary shares, preferred stocks or preference shares, and exchange 
traded funds, excluding non-listed firms to solely assess the capital market performance vis-s-vis WCM. Listed firms by their requirements are obligated to submit their final accounts to the exchange's authorities and are expected to produce true and fair financial statements. Non-listed firms are likely to report under-stated profit as a way of evading corporate tax and so are unlikely to produce true and fair annual reports (Lazaridis and Tryfonidis, 2006). Financial information extracted from the annual reports of all 36 listed firms were obtained from the GSE Fact Book and the web sites of the firms. Abstraction methodology was espoused for harnessing financial information from the final accounts of the 36 listed firms.

Table 1. Industry Classification of Firms Listed on GSE.

\begin{tabular}{lcc}
\hline Industry & No. of Firms & Percentage (\%) \\
\hline Metal, Mining \& Oil & 4 & 11.43 \\
Manufacturing \&Trading & 6 & 17.14 \\
Finance \& Insurance Services & 12 & 31.43 \\
Agric \& Agro Processing & 4 & 11.43 \\
Pharmacy \& Beverage & 5 & 14.29 \\
IT \& Paper conversion & 5 & 14.29 \\
\hline TOTAL & 36 & 100.00 \\
\hline
\end{tabular}

\section{Estimation technique}

This scientific inquiry fundamentally seeks to assess the influence of WCM on the performance of firms listed on the GSE. The study utilized dynamic panel Systems GMM i.e., Blundell and Bond (1998) estimation technique to establish the nexuses between WCM and FP as employed by Bétila, 2021; Musa, Metamilola and Bany-Ariffin, 2021; Liaqat et al 2021; Dodoo, Donkor and Appiah, 2021 among others.

The advantages of utilizing dynamic panel Systems GMM over the other econometric estimation techniques like the OLS, pooled OLS, two-stage least square, partial least square, FE, random effects (RE), maximum likelihood etc. are as follows: It does not eliminate cross-firm variations in the estimation (Asongu et al., 2018); It allows to take account of the dynamics of the phenomena under investigation; It allows residuals to be uncorrelated across individual observations (Gujurati. 2004); It has the ability to deal with unobserved heterogeneity (Briamah et al., 2021) and endogeneity problems (Matemilola et al., 2019), arising from reverse causality, simultaneity, functional form misspecification, measurement errors, omitted variables, sample selection error all of which causes autocorrelation/serial correlation; ability to deal with heteroscedasticity issues (Wooldridge, 2001); ability to deal with non-linearity typically of time series that invalidate their properties (Alege and Osundipc, 2013); it allows econometric models to be specified whilst avoiding often unnecessary assumptions such as the need to specify a particular distribution for the error term; it allows estimation under theoretically sound restrictions and it performs well with highly persistent variables i.e., dynamic panel System GMM performs well even if the values of the variables do not deviate systematically from their 'paths' over time (i.e., model approaches random walk); It provides better results i.e., low bias with more accurate standard deviation (Windmeijer, 2005); It allows to control the presence of inter-individual dependence and allow to limit not only the proliferation of instruments but also to restrict the over-identification of the model (Baltagi, 2013).

GMM estimators is attractive in view of its robustness to failures of auxiliary distributional assumptions that are not needed to focal parameters (Windmeijer, 2005). Sophisticated GMM estimators are indispensable for complex estimation issues (Betila, 2021). According to Wooldridge (2001), GMM models are better tools for analyzing panel data especially panels with unprotected effects even with weak assumptions. GMM is a method that uses the two sets of population moment conditions i.e., mean and variance to minimize the asymptotic variance among the method of moment estimators of the population (Wooldridge, 2001). The dynamic panel System GMM is preferred in this inquiry in view of the fact that it presents the lowest bias and highest precision when the time dimension (t) in the panel is small in this case 9 years when compared to other widely used estimators like the FE or the difference GMM (Baltagi, 2013). The dynamic panel System GMM overcomes the finite sample bias in the present of weak instruments that the single-equation Difference GMM is subject to (Wooldridge, 2001). This current inquiry, treated all predictors strictly as exogenous except the lagged outcome variables used as instruments in our models.

By lagging the prognostic variables and utilizing them as explanatory variables in the dynamic panel model, it aids in solving endogeneity problems as well as help control for reverse causality and spurious/bias/inconsistencies results triggered by omitted variables. 
Variables

FP used as prognostic variable was measured by both accounting profitability proxy by ROA measured as earnings before interest and tax (EBIT) divided by total assets as used by Braimah et al., 2021; Obeng et al.2021 and market value measure or metric or indicator proxy by TQ measured as equity market value plus liability book value divided by equity book value plus liability book value as used by Abuzayed (2012). With respect to the independent/explanatory variables, nine predictors/regressors were espoused in this study and categorized into four main WCM variables and five control variables. The first WCM regressor is INV defined as the number of days inventories are kept by the company before sold. It is computed as $365 \mathrm{x}$ inventories/cost of goods sold. The longer the period, the more resource invested in inventory vis-à-vis a specific business function.

The second WCM predictor is AR defined as the number of days goods sold on credit remain in account receivable until paid. It is computed as $365 \mathrm{x}$ account receivable/sales. High values/figures indicate more investment in accounts receivable, implying it takes a longer time for debtors to settle their liabilities. The third WCM explanatory variable is AP defined as the number of days goods purchased on credit remain in account payable until paid. It is computed as 365 $\mathrm{X}$ account payable/purchases. High values/figures imply that, the firm takes long time to settle its creditors. Furthermore, CCC which is a much more all-inclusive metric is used as a measure of WCM. CCC is the number of days between settling debt owed suppliers and collecting cash from credit sales. Low values of CCC are preferred as it indicates low investment in CA and high liquidity implying investment in short term CA can easily be changed into cash. High values suggest more investment in CA which requires financing needs. CCC is computed as INV + AR - AP.

The squared values of these four main independent variables i.e., $\mathrm{INV}^{2}, \mathrm{AR}^{2}, \mathrm{AP}^{2} \mathrm{CCC}^{2}$ were captured as part of the regression models to take care of the likelihood of any non-linear relationship between WCM and FP as used by Briamah et al. 2021, Altaf \& Shah, 2018; Baños-Caballero et al., 2012.

The study controlled for GROW, SIZE, LEV, CR and FFA, as done by other researchers in extant literature (Briamah et al. 2021, Obeng et al.2021, Altaf \& Shah, 2018; Bhatia \& Srivastava, 2016).

GROW was measured as current sales less previous year's sales divided by previous year's sales $\mathrm{Sales}_{1}-\mathrm{Sales}_{0} / \mathrm{Sales}_{0}$. SIZE was computed as the natural logarithm of total assets [Intotal assets]. LEV was computed as total debt/total asset. $\mathrm{CR}$ was computed as CA/CL. FFA was computed as fixed financial assets/total assets.

\section{Empirical Model Specification}

This scientific inquiry fundamentally seeks to assess the influence of WCM on the performance of firms listed on the GSE. The study utilized dynamic panel System GMM i.e., Blundell and Bond (1998) estimation technique to establish the nexuses between WCM and FP as utilized in extant literature (Bétila, 2021; Musa, Metamilola and Bany-Ariffin, 2021; Liaqat et al 2021; Dodoo, Donkor and Appiah, 2021). The study utilized two measures of FP i.e., accounting profitability proxy by ROA and market-based indicator/metric proxy by TQ. The first set of models regressed ROA for firm $i$ at time $t$ on WCM constituents/variables as well as the associated control variables included in the models as follows:

$\mathrm{ROA}_{\mathrm{it}}=\beta_{0}+\beta_{1} \mathrm{ROA}_{\mathrm{it}-1}+\beta_{2} \mathrm{INV}_{\mathrm{it}}+\left[\beta_{3} \mathrm{INV}_{\mathrm{it}}\right]^{2}+\beta_{4} \mathrm{GROWit}+\beta_{5} \mathrm{SIZE}_{\mathrm{it}}+\beta_{6} \mathrm{LEV}_{\mathrm{it}}+\beta_{7} \mathrm{CR}_{\mathrm{it}}+\beta_{8} \mathrm{FFA}_{\mathrm{it}}+\mu_{\mathrm{i}}+\lambda_{\mathrm{t}}+\varepsilon_{\mathrm{it}} \ldots \ldots \ldots$ [MODEL 1]

$\mathrm{ROA}_{\mathrm{it}}=\beta_{0}+\beta_{1} \mathrm{ROA}_{\mathrm{it}-1}+\beta_{2} \mathrm{AR}_{\mathrm{it}}+\left[\beta_{3} \mathrm{AR}_{\mathrm{it}}\right]^{2}+\beta_{4} \mathrm{GROWit}+\beta_{5} \mathrm{SIZE}_{\mathrm{it}}+\beta_{6} \mathrm{LEV}_{\mathrm{it}}+\beta_{7} \mathrm{CR}_{\mathrm{it}}+\beta_{8} \mathrm{FFA}_{\mathrm{it}}+\mu_{\mathrm{i}}+\lambda_{\mathrm{t}}+\varepsilon_{\mathrm{it}} \ldots \ldots \ldots \ldots \ldots$ [MODEL 2]

$\mathrm{ROA}_{\mathrm{it}}=\beta_{0}+\beta_{1} \mathrm{ROA}_{\mathrm{it}-1}+\beta_{2} \mathrm{AP}_{\mathrm{it}}+\left[\beta_{3} \mathrm{AP}_{\mathrm{it}}\right]^{2}+\beta_{4} \mathrm{GROWit}+\beta_{5} \mathrm{SIZE}_{\mathrm{it}}+\beta_{6} \mathrm{LEV}_{\mathrm{it}}+\beta_{7} \mathrm{CR}_{\mathrm{it}}+\beta_{8} \mathrm{FFA}_{\mathrm{it}}+\mu_{\mathrm{i}}+\lambda_{\mathrm{t}}+\varepsilon_{\mathrm{it}} \ldots \ldots \ldots \ldots .$. [MODEL 3]

$\mathrm{ROA}_{\text {it }}=\beta_{0}+\beta_{1} \mathrm{ROA}_{\mathrm{it}-1}+\beta_{2} \mathrm{CCC}_{\mathrm{it}}+\left[\beta_{3} \mathrm{CCC}_{\mathrm{it}}\right]^{2}+\beta_{4} \mathrm{GROWit}+\beta_{5} \mathrm{SIZE}_{\mathrm{it}}+\beta_{6} \mathrm{LEV}_{\mathrm{it}}+\beta_{7} \mathrm{CR}_{\mathrm{it}}+\beta_{8} \mathrm{FFA}_{\mathrm{it}}+\mu_{\mathrm{i}}+\lambda_{\mathrm{t}}+\varepsilon_{\text {it }} \ldots \ldots$ [MODEL 4]

The second set of models regressed TQ for firm $i$ at time $t$ on WCM variables as well as the associated control variables as follows:

$\mathrm{TQ}_{\mathrm{it}}=\beta_{0}+\beta_{1} \mathrm{TQ}_{\mathrm{it}-1}+\beta_{2} \mathrm{INV}_{\mathrm{it}}+\left[\beta_{3} \mathrm{INV}_{\mathrm{it}}\right]^{2}+\beta_{4} \mathrm{GROWit}+\beta_{5} \mathrm{SIZE}_{\mathrm{it}}+\beta_{6} \mathrm{LEV}_{\mathrm{it}}+\beta_{7} \mathrm{CR}_{\mathrm{it}}+\beta_{8} \mathrm{FFA}_{\mathrm{it}}+\mu_{\mathrm{i}}+\lambda_{\mathrm{t}}+\varepsilon_{\text {it }} \ldots \ldots \ldots \ldots$ [MODEL 5]

$\mathrm{TQ}_{\mathrm{it}}=\beta_{0}+\beta_{1} \mathrm{TQ}_{\mathrm{it}-1}+\beta_{2} \mathrm{AR}_{\mathrm{it}}+\left[\beta_{3} \mathrm{AR}_{\mathrm{it}}\right]^{2}+\beta_{4} \mathrm{GROWit}+\beta_{5} \mathrm{SIZE}_{\mathrm{it}}+\beta_{6} \mathrm{LEV}_{\mathrm{it}}+\beta_{7} \mathrm{CR}_{\mathrm{it}}+\beta_{8} \mathrm{FFA}_{\mathrm{it}}+\mu_{\mathrm{i}}+\lambda_{\mathrm{t}}+\varepsilon_{\mathrm{it}}$.

[MODEL 6]

$\mathrm{TQ} Q_{i t}=\beta_{0}+\beta_{1} \mathrm{TQ}_{\mathrm{it}-1}+\beta_{2} \mathrm{AP}_{\mathrm{it}}+\left[\beta_{3} \mathrm{AP}_{\mathrm{it}}\right]^{2}+\beta_{4} \mathrm{GROWit}+\beta_{5} \mathrm{SIZE}_{\mathrm{it}}+\beta_{6} \mathrm{LEV}_{\mathrm{it}}+\beta_{7} \mathrm{CR}_{\mathrm{it}}+\beta_{8} \mathrm{FFA}_{\mathrm{it}}+\mu_{\mathrm{i}}+\lambda_{\mathrm{t}}+\varepsilon_{\mathrm{it}}$

[MODEL 7]

$\mathrm{TQ}_{\mathrm{it}}=\beta_{0}+\beta_{1} \mathrm{TQ}_{\mathrm{it}-1}+\beta_{2} \mathrm{CCC}_{\mathrm{it}}+\left[\beta_{3} \mathrm{CCC}_{\mathrm{it}}\right]^{2}+\beta_{4} \mathrm{GROWit}+\beta_{5} \mathrm{SIZE}_{\mathrm{it}}+\beta_{6} \mathrm{LEV}_{\mathrm{it}}+\beta_{7} \mathrm{CR}_{\mathrm{it}}+\beta_{8} \mathrm{FFA}_{\mathrm{it}}+\mu_{\mathrm{i}}+\lambda_{\mathrm{t}}+\varepsilon_{\mathrm{it}} \ldots$ [MODEL 8]

Where, $\mathrm{ROA}_{\mathrm{it}}$ and $\mathrm{TQ}_{\mathrm{it}}$ are accounting measure of profitability and market-based performance metric, respectively for firm $i$ at year $t$ i.e., the dependent/outcome/prognostic variable. $\mathrm{ROA}_{\mathrm{it}-1}$ and $\mathrm{TQ}_{\mathrm{it}-1}$ are the one-year lags of ROA and TQ, respectively. $\mathrm{INV}_{\mathrm{it}}, \mathrm{AR}_{\mathrm{it}}$, and $\mathrm{AP}_{\mathrm{it}}$ are the $\mathrm{WC}$ constituent for firm $i$ at year $t$ and denotes number of days inventory, number of days account receivable and number of days account payable, respectively. $\mathrm{CCC}_{\mathrm{it}}$ denote cash conversion cycle for firm $i$ at year $t$, an all-inclusive measure of $\mathrm{WCM}$. $\mathrm{INV}_{\mathrm{it}}{ }^{2}, \mathrm{AR}_{\mathrm{it}}{ }^{2}, \mathrm{AP}_{\mathrm{it}}{ }^{2}$ and $\mathrm{CCC}_{\mathrm{it}}{ }^{2}$ are the square of number of days inventory, number of days account receivable number of days account payable and cash conversion cycle, respectively. 
$\mathrm{GROW}_{\mathrm{it}}, \mathrm{SIZE}$ it, LEV $\mathrm{it}, \mathrm{CR}_{\mathrm{it}}$, and FFA $\mathrm{it}_{\mathrm{it}}$ are the control variables for firm $i$ at year $t$, and they denote growth in sales level, firm size, firm leverage or capital structure; current ratio and the ratio of financial assets to total assets, respectively. $\beta_{0}$ is the constant/intercept. $\beta_{1}, \beta_{2}, \beta_{8}$ denotes the beta parameters to be estimated. $\mu_{i}$ is unobservable heterogeneity and $\lambda_{t}$ is time dummy variable. The subscript $i$ and $t$ represent firm and time dimensions, respectively. $\varepsilon_{\mathrm{it}}$ is the stochastic disturbance term.

\section{REDEARCH FINDINGS AND DISCUSSION}

\section{Descriptive Statistics}

A summary descriptive statistic of the outcome and explanatory variables for the study is presented in Table 2 . The mean profitability i.e., ROA of the 36 listed firms is 19 per cent, suggesting that, investors made on the average 19 per cent return on their capital contribution both debt and equity to listed firms on the GSE. Most of the listed firms on the average seems underperforming so far as TQ as a performance measure is concern, recording a mean TQ ratio of 0.63 . This suggests that, a greater number of the listed firms did not break-even i.e., the listed firm's replacement costs were less than their current market values. The 36 listed firms recorded an average CCC of 154 days.

It takes averagely, 99 days for the 36 listed firms to sell goods in stock or store and on the average, get paid for goods sold on credit after 145 days, whilst the listed firms make payments to their suppliers for goods purchased on credit after 90 days. This is an indication of the requirement of extra capital or funds to finance the working capital needs created by this gap. Average firm's growth rate with respect to sales was 24 per cent, with a 3.85 mean firm size. The firms average financial leverage was $55 \%$, depicting a slightly leverage or geared firms i.e., more than half of the financing of the assets of the 36 listed firms came from debt listed on the GSE. The 36 listed firms recorded an average CR of 1.75, an indication of the listed firms' ability to raise adequate CAs to take care of their CLs. Average FFA for the 36 listed firms was 25 per cent of total assets, signaling that, a quarter of the listed firms' total assets came from fixed financial assets.

Table 2. Descriptive Summary Statistics of Dependent and Independent variables.

\begin{tabular}{lccccc}
\hline Variables & Obs & Mean & Std. Dev. & Min & Max \\
\hline ROA (\%) & 324 & 0.19 & 0.10 & -0.11 & 0.95 \\
\hline Tobin's Q & 324 & 0.63 & 0.35 & 0.13 & 1.48 \\
\hline INV (days) & 324 & 99.00 & 45.35 & 29.67 & 225.78 \\
\hline AR (days) & 324 & 145.00 & 124.24 & 15.47 & 412.35 \\
\hline AP (days) & 324 & 90.00 & 55.25 & 20.75 & 242.57 \\
\hline CCC (days) & 324 & 154.00 & 101.35 & -34.25 & 649.55 \\
\hline GROW (\%) & 324 & 0.24 & 0.07 & -1.00 & 1.25 \\
\hline SIZE & 324 & 3.85 & 0.32 & 0.82 & 6.85 \\
\hline LEV (\%) & 324 & 0.55 & 0.19 & 0.10 & 0.95 \\
\hline CR & 324 & 1.75 & 0.22 & 0.06 & 2.25 \\
\hline FFA (\%) & 324 & 0.25 & 0.15 & 0.05 & 0.65 \\
\hline
\end{tabular}

Note: CCC can assume both negative and positive signs. A positive sign implies the number of days a firm must borrow or tie up capital while awaiting payment from a customer. A negative sign reveals the number of days a firm has received cash from sales before it must pay its suppliers (Hutchison et al., 2007).

Source: Author's Computations with STATA (2021)

\section{Correlation Analysis}

Correlation test was performed to determine whether the issue of multicollinearity exist and also to establish the relationships between the outcome variables and the independent variables as well as ascertain the associations among all the explanatory variables. With respect to multicollinearity, the main reason for conducting this test was to avoid a situation where two or more independent variables with high correlation would be included in a regression model. Table 3 depict the correlation matrix with ROA and TQ as the prognostic variables against the other WCM regressors.

Table 3. Correlation Analysis/Matrix for Dependent and Independent Variables.

\begin{tabular}{|c|c|c|c|c|c|c|c|c|c|c|c|}
\hline & ROA & TQ & INV & AR & $\mathrm{AP}$ & $\mathrm{CCC}$ & GROW & SIZE & LEV & $\mathrm{CR}$ & FFA \\
\hline ROA & 1 & & & & & & & & & & \\
\hline TQ & 0.36 & 1 & & & & & & & & & \\
\hline INV & $-0.42 * *$ & $-0.31 * *$ & 1 & & & & & & & & \\
\hline $\mathrm{AR}$ & $-0.47 * *$ & $-0.42 * *$ & 0.29 & 1 & & & & & & & \\
\hline$\overline{\mathrm{AP}}$ & $0.39 * *$ & $0.12 * *$ & 0.26 & 0.55 & 1 & & & & & & \\
\hline
\end{tabular}




\begin{tabular}{|c|c|c|c|c|c|c|c|c|c|c|c|}
\hline $\mathrm{CCC}$ & $-0.36^{* *}$ & $-0.24 * *$ & $0.37 * *$ & $0.35^{*}$ & $0.50 * * *$ & 1 & & & & & \\
\hline GROW & $0.27 * *$ & $0.34 * *$ & $0.59 * * *$ & $0.29 *$ & $0.41 *$ & $0.39 * * *$ & 1 & & & & \\
\hline SIZE & $0.15 * *$ & $0.44 * *$ & 0.25 & 0.31 & $0.19 * * *$ & 0.28 & $0.14^{*}$ & 1 & & & \\
\hline LEV & $-0.56^{* *}$ & $-0.31 * *$ & $0.41 * *$ & $0.30 * *$ & 0.39 & 0.41 & 0.26 & 0.4 & 1 & & \\
\hline $\mathrm{CR}$ & $0.25 * *$ & $0.41 * *$ & 0.31 & 0.16 & 0.44 & 0.51 & $0.32 * * *$ & 0.33 & 0.17 & 1 & \\
\hline FFA & $0.42 * *$ & $0.22 * *$ & $0.43 * *$ & $0.40 * *$ & 0.33 & $0.3^{*}$ & 0.77 & 0.19 & $0.31 * * *$ & $0.39 *$ & 1 \\
\hline
\end{tabular}

Note: $* * *, * *$ and $*$ denote significance at the $1 \%, 5 \%$, and $10 \%$ levels, respectively.

Source: Author's computations with STATA (2021)

The correlation matrix for the WCM regression models reveal that, all the independent variables can be included in the regression models as the correlation between them was not high i.e., the correlation between the independent variables were all below 0.6 and is considered satisfactory (Hair and associate, 2016; Gujarati, 2004).

The correlation matrix reveals a negative and significant association between CCC, as well as two of its constituents i.e., INV and AR and both ROA and TQ, but a significant and positive correlation between AP and both ROA and TQ.

The indication is that, the longer the CCC emanating from longer periods of INV and AR but shorter period of AP, the less the efficacy in managing the business' WC and hence liquidity. GROW, SIZE, CR and FFA all had positive association with both ROA and TQ whilst LEV had negative association with both ROA and TQ, an indication of the over-bearing effect of cost of borrowing i.e., interest on both profitability i.e., ROA and market values i.e., TQ of listed firms in Ghana.

\section{Regression Assumptions Testing}

The authors ensured that the standardized multivariate linear regression models placate all the assumptions [Normality, heteroskedasticity, autocorrelation, endogeneity and heterogeneity] necessary under multiple linear regression analysis to avoid a situation where an assumption would be violated which will result in biased/spurious outcomes. The assumption testing guarantee that the models are fit for regression. The regression assumption testing results is presented in Table 4.

Table 4. Testing Regression Assumptions Summary.

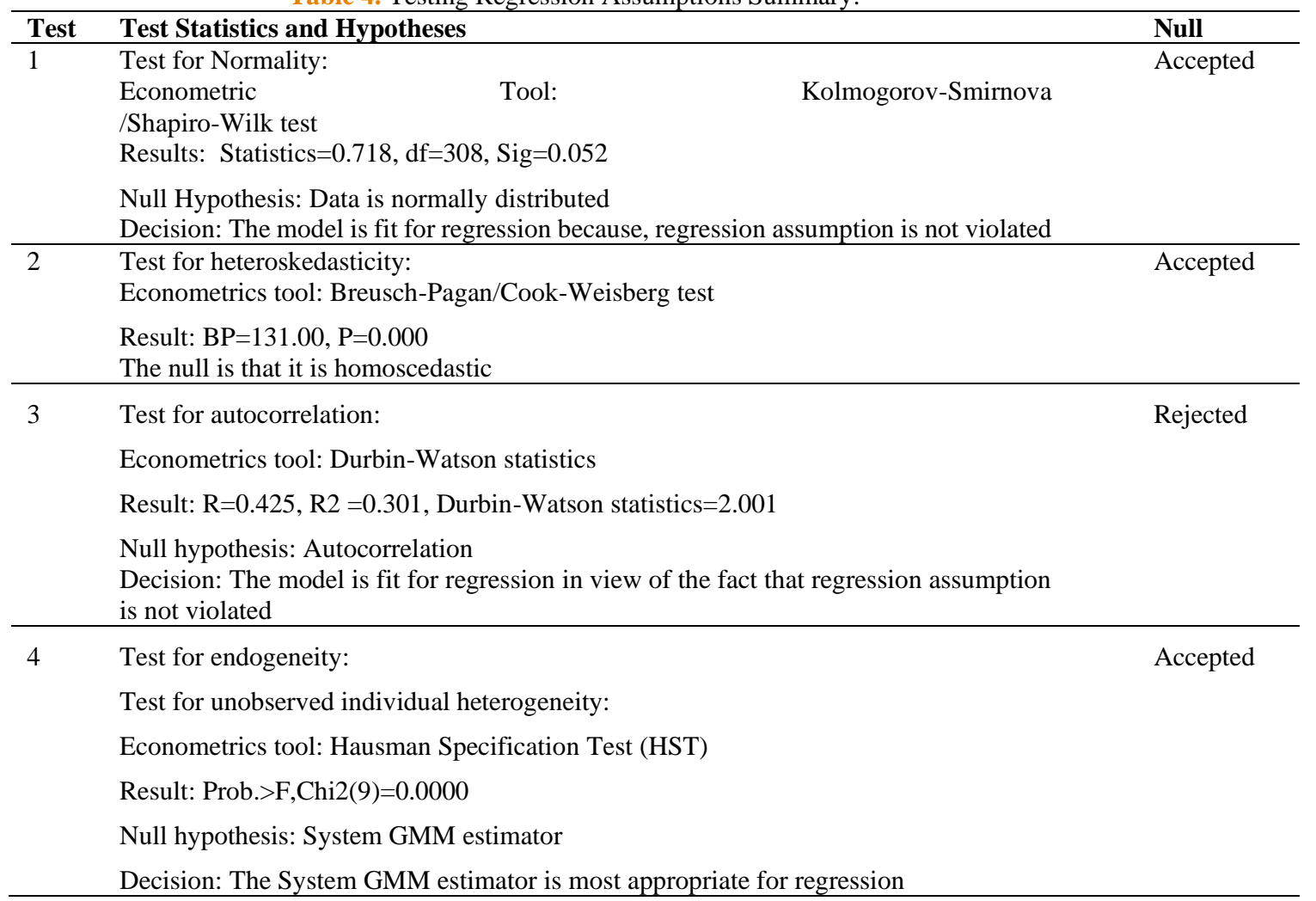

Source: Author's computation with STATA (2021)

\section{Research Findings and Discussion}

Multiple linear regression analysis is employed to assess the relationship between WCM variables i.e., INV, AR, AP, CCC and other control variables i.e., GROW, SIZE, LEV, CR and FFA and FP proxies by ROA and TQ of the 36 listed firms in Ghana. The results of the robust Blundell \& Bond (1998) dynamic panel Systems of GMM regression are shown in Table 5 with ROA as outcome/prognostic/dependent variable. This vigorous estimation technique was employed because, it has the ability to deal with the problems of endogeneity and unobservable heterogeneity in the regression 
models. Again, the dynamic panel Systems of GMM has the ability to produce consistent and unbiased results. The authors performed Sargan (1958) test in other to establish instrument validity of the study findings/results and as depicted on tables 5 and 6, all the study results proofed to be instrumentally valid with AR (1) and AR (2) greater than 10\% i.e., the Sargan (1958) test did not show any problem of overidentification, giving credibility and authority to instrument validity and at the same time producing consistence, reliable and more efficient results for the regression models.

The regression models also passed the test for no second-order serial correlation in errors as depicted in the insignificant $\mathrm{p}$-values of the $\mathrm{m}$ statistics reported on the regression results tables $5 \& 6$.

Table 5. System GMM Regression Results of WCM Effect on ROA as the dependent variable.

\begin{tabular}{|c|c|c|c|c|}
\hline VARIABLES & Model 1 & Model 2 & Model 3 & Model 4 \\
\hline Constant & -1.7277 & -1.0432 & -1.9934 & -1.3512 \\
\hline \multicolumn{5}{|c|}{ Focal/Main Predictors } \\
\hline $\operatorname{ROA}_{(t-1)}$ & $\begin{array}{l}0.5021 * * * \\
(0.0121)\end{array}$ & $\begin{array}{l}0.2851 * * * \\
(0.0001)\end{array}$ & $\begin{array}{l}0.3642 * * * \\
(0.0039)\end{array}$ & $\begin{array}{l}0.2901 * * * \\
(0.0029)\end{array}$ \\
\hline INV & $\begin{array}{l}-0.0617 * * \\
(0.0031)\end{array}$ & & & \\
\hline $\mathrm{INV}^{2}$ & $\begin{array}{l}-0.0032 \\
(0.0011)\end{array}$ & & & \\
\hline AR & & $\begin{array}{l}-0.0767 * * \\
(0.0085)\end{array}$ & & \\
\hline $\mathrm{AR}^{2}$ & & $\begin{array}{l}-0.0045 \\
(0.0024) \\
\end{array}$ & & \\
\hline AP & & & $\begin{array}{l}0.0585 * * \\
(0.0098)\end{array}$ & \\
\hline $\mathrm{AP}^{2}$ & & & $\begin{array}{l}-0.0025 \\
(0.0011) \\
\end{array}$ & \\
\hline $\mathrm{CCC}$ & & & & $\begin{array}{l}-0.0842 * * \\
(0.022)\end{array}$ \\
\hline $\mathrm{CCC}^{2}$ & & & & $\begin{array}{l}0.0042 \text { *** } \\
(0.0021)\end{array}$ \\
\hline \multicolumn{5}{|l|}{ Control Variables } \\
\hline GROW & $\begin{array}{l}0.0509 * * * \\
(0.0101)\end{array}$ & $\begin{array}{l}0.0519 * * * \\
(0.0212)\end{array}$ & $\begin{array}{l}0.0534 * * * \\
(0.1255)\end{array}$ & $\begin{array}{l}0.0514 * * * \\
(0.0231)\end{array}$ \\
\hline SIZE & $\begin{array}{l}0.0487 * * * \\
(0.0221) \\
\end{array}$ & $\begin{array}{l}0.0492 * * * \\
(0.0052)\end{array}$ & $\begin{array}{l}0.0456 * * * \\
(0.0234) \\
\end{array}$ & $\begin{array}{l}0.0504^{* * * *} \\
(0.0214)\end{array}$ \\
\hline LEV & $\begin{array}{l}-0.0387^{*} \\
(0.0043) \\
\end{array}$ & $\begin{array}{l}-0.0392^{*} \\
(0.0072) \\
\end{array}$ & $\begin{array}{l}-0.0378^{*} \\
(0.0024) \\
\end{array}$ & $\begin{array}{l}-0.0358^{*} \\
(0.0021) \\
\end{array}$ \\
\hline $\mathrm{CR}$ & $\begin{array}{l}0.0221^{*} \\
(0.0084)\end{array}$ & $\begin{array}{l}0.0262 * \\
(0.0063)\end{array}$ & $\begin{array}{l}0.2241^{*} \\
(0.0021)\end{array}$ & $\begin{array}{l}0.2824^{*} \\
(0.0014)\end{array}$ \\
\hline FFA & $\begin{array}{l}0.0172 * * * \\
(0.0044)\end{array}$ & $\begin{array}{l}0.0137 * * * \\
(0.0038)\end{array}$ & $\begin{array}{l}0.0112^{* * * *} \\
(0.0012)\end{array}$ & $\begin{array}{l}0.0121 * * * \\
(0.0051)\end{array}$ \\
\hline \multicolumn{5}{|l|}{ Weighted Statistics } \\
\hline$R^{2}$ & 0.6851 & 0.6904 & 0.6731 & 0.7015 \\
\hline Adjusted $\mathrm{R}^{2}$ & 0.6795 & 0.6855 & 0.6624 & 0.6901 \\
\hline S.E. of Regression & 0.3395 & 0.3405 & 0.3058 & 0.4016 \\
\hline F-Statistics & 195.25 & 198.55 & 194.77 & 199.78 \\
\hline Prob(F-statistics) & 0.0000 & 0.0000 & 0.0000 & 0.0000 \\
\hline Mean VIF & 1.6672 & 1.8824 & 1.4155 & 1.9151 \\
\hline \multicolumn{5}{|l|}{ Sargan Test: } \\
\hline Prob $>\chi^{2}$ & 0.2885 & 0.3851 & 0.4251 & 0.4017 \\
\hline AR(1) $p$-value & 0.3249 & 0.1271 & 0.1589 & 0.1924 \\
\hline $\operatorname{AR}(2) p$-value & 0.9455 & 0.2775 & 0.3821 & 0.4021 \\
\hline $\mathrm{m}_{2}$ & 0.8013 & 0.4872 & 0.7251 & 0.6923 \\
\hline Observations & 324 & 324 & 324 & 324 \\
\hline Number of firms & 36 & 36 & 36 & 36 \\
\hline
\end{tabular}

Source: Authors' computations with STATA (2021).

Note: The robust standard errors (SEs) are reported in parentheses. The four models $(1,2,3$, and 4) recorded highest VIF, though not reported, of 2.226 , $2.435,2.089$, and 2.514 , respectively for the explanatory variables. These VIFs fall below the criteria of 10, suggesting the absence of multicollinearity (Kennedy, 1998). Each model estimation incorporated both time and industry dummies, but the estimates are not reported. ***, ** and * denote significance at the $1 \%, 5 \%$, and $10 \%$ levels, respectively. 
Using ROA as the dependent variable, the regression results indicate that, the explanatory variables explained $67.95 \%$, $68.55 \%, 66.24 \%$ and $69.01 \%$ of the variance in the outcome variables for models $1,2,3$ and 4 , respectively.

The F-statistics demonstrates satisfactory validity of the estimated models i.e., the balanced panel regression models have good fit. Empirical regression results from table 5, reveals a significantly $p<0.05$, inverse i.e., $\beta_{2}=-0.0617$ association between INV and ROA, implying that profitable firms recorded high inventory turnover. This means, the lower the number of days inventory, the higher the ROA and vice versa and therefore we fail to reject hypothesis $1\left[\mathrm{H}_{1}\right]$ as the results confirm that INV influenced ROA significantly and negatively. Likewise, the squared INV INV ${ }^{2}$ depicts negative association with ROA, i.e., $\beta_{3}=-0.0032$ but this association is insignificant. The combined effect yields an overall significantly negative association with ROA. This negative association indicates that, listed companies maximize profitability via maintaining low inventory levels coupled with a reduction in inventory management related costs such as obsolescence, insurance premium, theft \& embezzlement among others. This finding is in line the findings of researchers like Ponsian, Chrispana, Tago \& Mkiibi (2014), Kodithuwakku (2015), Akomeah \& Frimpong (2019), Phuong \& Hung (2020), Braimah et al. (2021) etc. but at loggerheads with the findings of scholars such as Prempeh (2016) and Mathuva (2010) who found direct/positive associations between INV and ROA.

The study's results also reveal a statistically significant $\mathrm{p}<0.05$, negative i.e., $\beta_{2}=-0.0767$ relationship between $\mathrm{AR}$ and its quadratic version $\mathrm{AR}^{2}$ and ROA. This means that, the shorter the AR period i.e., lower AR value, the higher the profitability i.e., ROA. The combined effect implies that, profitable firms were able to collect their account receivable from their clientele base within a relatively shorter periods which influenced their profitability positively and therefore we fail to reject hypothesis $2\left[\mathrm{H}_{2}\right]$. This finding is consistent with the findings of Akoto, Awunyo-Vito and Angmor (2013), Gachira, Chiwanzwa, Nkomo \& Chikore (2014), Kodithuwakku (2015) but inconsistent with the findings of Kasozi (2017), Akomeah \& Frimpong (2019), Briamah et al. (2021) who found direct/positive associations between AR and ROA.

Empirical results presented in table 5 depicts a significant $p<0.05$ and positive $\beta_{2}=0.0585$ association between AP and its quadratic form $\mathrm{AP}^{2}$ and ROA, an indication of the unwillingness of profitable firms to settle their liabilities i.e., account payable on a faster note. Profitable firms prefer to pay their creditors as late as possible whilst striving to collect their account receivable as fast as possible as a means of managing their WC or liquidity efficiently. This positive association between AP and ROA gives an indication that, listed firms in Ghana can maximize profitability by depending largely on trade credit facilities from suppliers. We therefore fail to reject hypothesis $3\left[\mathrm{H}_{3}\right]$. This result is in line with the findings of researchers like Ponsian, Chrispana, Tago \& Mkiibi (2014), Kodithuwakku (2015), Rahman, Iqbal \& Nadeem (2019), Akomeah \& Frimpong (2019), Kasahun (2020), Braimah et al. (2021), but at caretta with findings such as Ponsian, Chrispana, Tago \& Mkiibi (2014), Kasozi (2017), Evci \& Sak (2018) and Phuong \& Hung (2020).

The study findings in table 5 shows a statistically significant i.e., $\mathrm{p}<0.05$ concave quadratic or inverted U-shaped association between WCM, proxy by CCC and ROA, as CCC recorded a negative beta coefficient value i.e., $\beta_{2}<0$ and its corresponding squared beta coefficient $\mathrm{CCC}^{2}$ value was positive $\beta_{3}{ }^{2},>0$ and statistically significant at $1 \%$. This finding support evidence in theory, as the reduction in CCC results in improved firm profitability whilst lengthening of the CCC influenced firm profitability negatively. This finding combined effect show that, there is an optimum WCM level that maximizes the performance of firms listed on the GSE. Explicitly, the positive section depicts that listed firms can improve their profitability with fewer periods of CCC i.e., the lower the CCC period, the more profitable the firm is and vice versa.

This is because listed firms that are profitable, adopt aggressive working capital policy or approach where, limited resources are channeled into CA via low inventory holdings and limited extension of credit facilities to customers, culminating in less account receivable and less cost associated with administering account receivable, coupled with delays in settling account payable, which improves the liquidity position of firms reflecting in improved profitability. In addition, this indirect/negative/inverse association between CCC and ROA can be attributed to listed firm's characteristic nature of maintaining shortened CCC periods and the substantial profit levels they achieve by virtue of the fact that, they control and run the entire capital market in Ghana. Listed firms that are more profitable usually maintain low inventory levels to minimize the opportunity cost of locking-up substantial amounts of funds unnecessarily in inventory. On the concave quadratic curve is also the optimum level where, profit maximization is achieved. The negative segment shows levels of account receivable beyond the ideal levels, where associated trade credit cost like legal costs and bad debt exceeds the

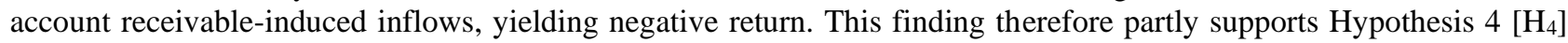
i.e., the inverse relationship between CCC and ROA but not in its entirety as the positive association between the squared form of CCC and ROA was ignored. This finding is consistent with previous research findings like Korent \& Orsag (2018), Altaf \& Shah (2018), Asiedu et al. (2020), Ahangar (2021) among others.

Except LEV, which recorded a negative association with ROA, all the other four control variables i.e., GROW, SIZE, CR \& FFA had positive associations with ROA for all four regression models i.e., model 1, model 2, model $2 \&$ model 4 and the relationships were statistically significant either at $1 \%$ or $10 \%$. GROW relates positively with ROA, meaning high growth in sales levels results in high profitability (ROA), thus supporting hypothesis $5\left(\mathrm{H}_{5}\right)$ and is consistent with the findings of Akinlo (2012), Kasahun (2020), Braimah et al. (2021) among others. Likewise, SIZE correlates directly with profitability (ROA), implying larger firms are more profitable than smaller firms in view of the fact that, larger firms can benefit from economies of scale as well as have access to external financing both debt and equity to boost their business operations, which smaller firms are at a disadvantage of. This finding supports hypothesis $6\left[\mathrm{H}_{6}\right]$ and is in line with the findings of Akoto, Awunyo-Vito \& Angmor (2013), Akomeah and Frimpong (2019), Braimah et al. (2021) among others but inconsistent with findings such as Nazir (2009). 
LEV correlate inversely with ROA, an indication of the consequences of over borrowing influence on firm profitability, as highly geared or leverage firms have to generate sufficient operating income [earnings before interest and $\operatorname{tax}(\mathrm{EBIT})]$ in order to take care of its cost of borrowing i.e., interest on borrowed funds to be able to make some decent profit and returns to its shareholders. This finding thus support hypothesis $7\left[\mathrm{H}_{7}\right]$ and is consistent with the findings of Yazdanfur \& Ohman (2015), Rahman, Iqbal \& Nadeem (2019), Kasahun (2020) but inconsistent with the findings of Braimah at al. (2021).

Again, CR relates positively with profitability (ROA), signifying that profitable firms employed consecutive working capital policies or approaches via maintaining sufficient investment in CA, which ensured firm profitability. This finding supports hypothesis $8\left[\mathrm{H}_{8}\right]$ and is in line with the findings of Akomeah \& Frimpong (2019), Rahman, Iqbal \& Nadeem (2019), among others. FFA also associate positively with firm profitability i.e., ROA, suggesting that, listed firms with high investment in fixed financial assets achieved/recorded high profitability levels. This finding supports hypothesis 9 $\left[\mathrm{H}_{9}\right]$ and is in line with the findings of Abuzayed (2012) and Asiedu et al. (2020). The regression results with Tobin's Q, as dependent variable is presented in Table 6.

Table 6. System GMM Regression Results of WCM Effect on Tobin's $Q$ as outcome variable.

\begin{tabular}{|c|c|c|c|c|}
\hline VARIABLES & Model 1 & Model 2 & Model 3 & Model 4 \\
\hline Constant & -0.6255 & -0.4531 & -0.7801 & -0.1423 \\
\hline \multicolumn{5}{|c|}{ Focal/Main Predictors } \\
\hline INV & $\begin{array}{l}-0.0099 * * \\
(0.0021)\end{array}$ & & & \\
\hline $\mathrm{INV}^{2}$ & $\begin{array}{l}-0.0025 \\
(0.0009) \\
\end{array}$ & & & \\
\hline AR & & $\begin{array}{l}-0.0097 * * \\
(0.0045)\end{array}$ & & \\
\hline $\mathrm{AR}^{2}$ & & $-0.0032(0.0014)$ & & \\
\hline AP & & & $\begin{array}{l}0.0099 * * \\
(0.0018)\end{array}$ & \\
\hline $\mathrm{AP}^{2}$ & & & $\begin{array}{l}-0.0022 \\
(0.0008)\end{array}$ & \\
\hline $\mathrm{CCC}$ & & & & $\begin{array}{l}-0.0772 * * \\
(0.021)\end{array}$ \\
\hline $\mathrm{CCC}^{2}$ & & & & $\begin{array}{l}-0.0039 * * * \\
(0.0011)\end{array}$ \\
\hline \multicolumn{5}{|l|}{ Control Variables } \\
\hline GROW & $\begin{array}{l}0.0419 * * * \\
(0.0099)\end{array}$ & $\begin{array}{l}0.0412 * * * \\
(0.0192)\end{array}$ & $\begin{array}{l}0.0502 * * * \\
(0.0025)\end{array}$ & $\begin{array}{l}0.0412 * * * \\
(0.0111)\end{array}$ \\
\hline SIZE & $\begin{array}{l}0.0399 * * * \\
(0.0221) \\
\end{array}$ & $\begin{array}{l}0.0312 * * * \\
(0.0022) \\
\end{array}$ & $\begin{array}{l}0.0444 * * * \\
(0.0202) \\
\end{array}$ & $\begin{array}{l}0.0478 * * * \\
(0.0212) \\
\end{array}$ \\
\hline LEV & $\begin{array}{l}-0.0284 * \\
(0.0029)\end{array}$ & $\begin{array}{l}-0.0272 * \\
(0.0067)\end{array}$ & $\begin{array}{l}-0.0378^{*} \\
(0.0024)\end{array}$ & $\begin{array}{l}-0.0248 * \\
(0.0047)\end{array}$ \\
\hline CR & $\begin{array}{l}0.0201 * \\
(0.0077)\end{array}$ & $\begin{array}{l}0.0462 * \\
(0.0057)\end{array}$ & $\begin{array}{l}0.2201 * \\
(0.0017)\end{array}$ & $\begin{array}{l}0.2754^{*} \\
(0.0024)\end{array}$ \\
\hline FFA & $\begin{array}{l}0.0165 * * * \\
(0.0037)\end{array}$ & $\begin{array}{l}0.0129 * * * \\
(0.0032)\end{array}$ & $\begin{array}{l}0.0103 * * * \\
(0.0011)\end{array}$ & $\begin{array}{l}0.0111 * * * \\
(0.0049)\end{array}$ \\
\hline \multicolumn{5}{|l|}{ Weighted Statistics } \\
\hline$R^{2}$ & 0.5951 & 0.4904 & 0.4731 & 0.5015 \\
\hline Adjusted $\mathrm{R}^{2}$ & 0.5101 & 0.4855 & 0.4624 & 0.4901 \\
\hline S.E. of Regression & 0.30554 & 0.3495 & 0.3077 & 0.4055 \\
\hline F-Statistics & 194.25 & 199.55 & 193.77 & 198.78 \\
\hline Prob(F-statistics) & 0 & 0 & 0 & 0 \\
\hline Mean VIF & 1.7172 & 1.8511 & 1.4555 & 1.9234 \\
\hline \multicolumn{5}{|l|}{ Sargan Test: } \\
\hline Prob $>\chi^{2}$ & 0.2556 & 0.3701 & 0.4466 & 0.4033 \\
\hline AR(1) p-value & 0.3107 & 0.1571 & 0.1889 & 0.1733 \\
\hline $\mathrm{AR}(2) \mathrm{p}$-value & 0.8701 & 0.5403 & 0.3729 & 0.4673 \\
\hline $\mathrm{m} 2$ & 0.7009 & 0.3695 & 0.6832 & 0.6412 \\
\hline Observations & 324 & 324 & 324 & 324 \\
\hline Number of firms & 36 & 36 & 36 & 36 \\
\hline
\end{tabular}

Note: The robust/vigorous standard errors (SEs) are reported in parentheses. The four models (1,2,3, and 4) recorded highest VIF, though not reported, of 2.234, 2.439, 2.099, and 2.554, respectively for the explanatory variables. These VIFs fall below the criteria of 10, suggesting the absence of multicollinearity (Kennedy, 1998). Each model estimation incorporated both time and industry dummies, but the estimates are not reported. ***, ** and $*$ denote significance at the $1 \%, 5 \%$, and $10 \%$ levels, respectively. 
The empirical results indicate that, the explanatory variables explained $51.01 \%, 48.55 \% 46.24 \%, 49.01 \%$ of the variance in the outcome variables. The F-statistics demonstrates satisfactory validity of the estimated models i.e., the balanced panel regression models have good fit. The empirical results depict that, CCC inversely influenced firm's WC requirements, signifying that firm's market value is enhanced via proper WCM.

Existing Investors in Ghana's capital market prefer firms with proper WCM mechanisms and they inculcate a firm's ability to efficiently management its liquidity/WC in their investment decision-making criteria. WCM proxies by CCC and its three constituents namely INV, AR \& AP, significantly influenced the profitability of firms listed on the GSE.

This can be attributed to proper corporate governance mechanisms, resulting in sufficient openness/transparency which influenced investors' decisions with regard to "where" and "when" to channel investor's scarce investment capital. Also, colossal institutions having huge growth in sales volumes and substantial investments in FFA end up with improved market value, were large fluctuations in operating income and highly geared institutions end up with small/minimal market value.

\section{CONCLUSION AND RECOMMENDATIONS}

This scientific inquiry empirically examined the influence of WCM on the performance of companies trading on the GSE. The research concentrated on all 36 firms listed on the GSE, covering a nine-year period, spanning from 2010 to 2019, generating a balanced panel of 324 observations. Utilizing a robust dynamic panel system GMM i.e., Blundell and Bond (1998) estimation techniques, which permits for the control of unobserved heterogeneity and endogeneity issues, the research concluded that, all the explanatory and control variables had statistically significant effect on FP proxies by ROA \& TQ. Except for AP, which had a positive relationship with FP i.e., ROA and TQ, all the other three main explanatory variables i.e., INV, AR \& CCC had statistically significant and inverse association with both accounting and market-value measures of performance i.e., ROA \& TQ. Similarly, except for LEV, which had an inverse relationship with FP i.e., ROA \& TQ, all the other four control variables i.e., GROW, SIZE, CR \& FFA had statistically significant and positive association with both ROA \& TQ.

It must be noted however that, CCC exhibited a quadratic concave or inverted U-shaped relationship with accounting measure of profitability i.e., ROA, an indication that, there exist an optimal working capital level, for firms listed on the GSE, where profitability can be maximized and as such, managers of listed firms in Ghana must make it a point to operate within the range of the optimal net WC level in order to maximize profitability. This study's results are generally in line with similar research findings in extant literature (Garcia-Tervely \& Martinez-Solano, (2007), Korent \& Orsag (2018), Altaf \& Shah (2018), Asiedu et al. (2020), Ahangar, 2021, among others).

There are numerous managerial/practical and scholarly implications of this scientific inquiry that is highly imperative and germane for top-level management and for imminent inquiry and improvement of the theory of WCM. The study findings reveals that WCM proxy by CCC and its individual constituent influenced FP either positively or negatively. In addition, findings suggest that, varying firm-specific elements like GROW, SIZE, CR, LEV and FFA influence FP differently, depending on the particular WCM constituent being considered.

This paper, thus, presents the need for top-level management to consider firm-specific features to formulate suitable WCM policies to aid maximize profitability.

This current inquiry's findings recommend to top-level management that, for firms to realize maximum profitability, top-level management should target operating within the range of the ideal/finest/optimal WC level, devoid of any interruptions and deviations. In addition, the study's findings extend the research on the importance of proper WCM and indicates that the association between WCM and firm profitability is non-linear i.e., inverted U-shaped or concave quadratic. Therefore, the study recommends the use of quadratic associations, testing for moderating or mediating associations in ensuing studies.

This inquiry is not without shortcomings. The research is entirely based on listed firms in Ghana, ignoring non-listed firms. Firm-specific control variables such as growth in GDP, Variability of net operating income, firm age etc. were all not captured in the dynamic panel system GMM estimation technique. For greater generalizability of the study's results, ensuing researches should consider other non-listed firms to have a broader picture of the effect of WCM on FP in Ghana.

\section{REFERENCES}

Abdul Razak, D. and Amin, H. (2020). The Effect of Financial Knowledge, Socialization, Attitude, and Skills on Malaysian SMEs' Performance. International Journal of Industrial Management, 8(1), 1-11.

Abor, J. (2005). International working capital practices of Ghanaian firms. Acta commercii, 5(1), 44-56.

Abdullah, S. \& Siddiqui, D. A. (2019). Working capital financing and corporate profitability of Pakistan manufacturing firms: Evidence from FMCG, cement \& chemical sector. Asian Journal of Economic Modelling, 7(2), 82-94. ttps://doi.org/10.18488/journal.8.2019.72.82.94

Abuhommous, A. A. A. (2017). The impact of offering trade credit on firms' profitability. The Journal of Corporate Accounting \& Finance, 28(6), 29-40. https://doi.org/10.1002/jcaf.22298

Abuzayed, B. (2012). Working capital management and firms' performance in emerging markets: the case of Jordan. In0ternational Journal of Managerial Finance, 8(2), 155-179. 
Adam, A. M. and Quansah, E. (2019). Effects of Working Capital Management Policies on Shareholders' Value: Evidence from Listed Manufacturing Firms in Ghana. PANOECONOMICUS, 66 (5) 659-686.

Adam, A. M., Quansah, E., \& Kawor, S. (2017). Working capital management policies and returns of listed manufacturing firms in Ghana. Scientific Annals of Economics and Business, 64(2), 255-269

Afrifa, G. A. (2013). Working Capital Management Components Importance Ranking Order by SMEs: Financial Directors Perspective. International Journal of Current Research, 6(1), 4631-4639

Agyei, S.K., Ansong, A, \& Oduro, M. I. (2013). Determinants of working capital requirement and policies of banks in Ghana. Ghanaian Journal of Economics, 1(1),

Agyemang, J. K., Yensu, J., and Otchere, M.I.O. (2019). The Impact of Working Capital Management on Profitability of Global Haulage Company, Ghana. Asian Journal of Economics, Business and Accounting, 12(4), 1-17. DOI: 10.9734/ajeba/2019/v12i430155

Ahangar, N. (2021). Is the relationship between working capital management and firm profitability nonlinear in Indian

SMEs? Small Enterprise Research, 28 (1) 23-35. https://doi.org/10.1080/13215906.2021.1872685

Akinlo, O. (2012). Effect of working capital on profitability of selected quoted firms in Nigeria. Global Business Review, 13(3), 367-381. https://doi.org/10.1177/097215091201300301.

Akomeah J. \& Frimpong S. (2019). Working capital management on profitability of listed manufacturing companies in Ghana. International Journal of Finance and Banking Research. 5(2), 29- 35

Akoto, R. K., Awunyo-Vitor, D., \& Angmor, P. L. (2013). Working capital management and profitability: Evidence from Ghanaian listed manufacturing firms. Journal of Economics and International Finance 5(9), 373-379

Aktas, N., Croci, E., \& Petmezas, D. (2015). Is working capital management value-enhancing? Evidence from firm performance and investments. Journal of Corporate Finance, 30, 98-113. https://doi.org/10.1016/j.jcorpfin.2014.12.008.

Alege, P. and Ogundipe, A. (2013). Sustaining Economic Development of West African Countries: A System GMM Panel Approach. MPRA Paper No. 51702, posted 25 Nov 2013.

Altaf, N., \& Shah, F. A. (2018). How does working capital management affect the profitability of Indian companies? Journal of Advances in Management Research, 15(3), 347-366. https:// doi.org/10.1108/JAMR-06-2017-0076

Alvarez, T., Sensini, L., Vazquez, M. (2021). Working Capital Management and Profitability: Evidence from an Emergent Economy. International Journal of Advances in Management and Economics, 11(1), 32-39.

Amponsah-Kwatiah, K., \& Asiamah, M. (2020). Working capital management and profitability of listed manufacturing firms in Ghana. International Journal of Productivity and Performance Management. https://doi.org/10.1108/IJPPM-02-2020-0043.

Anton, S.G. and Nucu, A.E. (2021). The Impact of Working Capital Management on Firm Profitability: Empirical Evidence from the Polish Listed Firms. Journal of Risk Financial Management, 14(1), 9; https://doi.org/10.3390/jrfm14010009.

Asiedu, M.A., Adegbedzi, D.K., Oduru, R., and Iddrisu, S. (2020). Working Capital Management Effect on Return on Equity: Evidence from Listed Manufacturing firms on Ghana Stock Exchange (GSE). International Journal of Finance and Accounting, 5(1), 47-66. DOI: https://doi.org/10.47604/ijfa.1125

Asongu, S.A. and Nwachukwu, J.C. (2018). Openness, ICT and Entrepreneurship in Sub-Saharan Africa. Inf Technol People 31(1), 278-303. https://doi.org/10.1108/ITP-02-2017-0033.

Attom, B. (2016). Working Capital Management as a financial Strategy to improve Profitability and Growth of Micro

and Small-Scale Enterprises (MSEs) Operating in the Central Region of Ghana. International Journal of Research in Commerce \& Management, 7(7), 42-50.

Baltagi, B. H. (2013). Econometric analysis of panel data (5th ed). John Wiley and Sons.

Bétila, R.R. (2021). The impact of Ease of Doing Business on economic growth: a dynamic panel analysis for African countries. SN Business and Economics, 1:114, 1-34. https://doi.org/10.1007/s43546-021-00143-9.

Baños-Caballero, S., García-Teruel, P. J., \& Martínez-Solano, P. (2012). How does working capital management affect the profitability of Spanish SMEs? Small Business Economics, 39(2), 517-529.

Bhatia, S., \& Srivastava, A. (2016). Working capital management and firm performance in emerging economies: Evidence from India. Management and Labour Studies, 41(2), 1-17.

Blundell, R., \& Bond, S. (1998). Initial conditions and moment restrictions in dynamic panel data models. Journal of Econometrics, 87, 115-143. doi:10.1016/ S0304-4076(98)00009-8

Braimah, A., Mu, Y., Quaye, I. and Abubakar, A. I. (2021). Working Capital Management and SMEs Profitability in Emerging Economies: The Ghanaian Case. SAGE Open, 1-16. DOI: 10.1177/2158244021989317.

Corsten, D., \& Gruen, T. W. (2004). Stock-outs cause walkouts. Harvard Business Review, 82(5), $26-28$.

Costa, B. R. D. (2014). Cash conversion cycle across industries [Doctoral dissertation]. NSBE-UNL.

Darkwah, K.A., Nortey, E.N.N., Asare-Kumi, A.A. and Asare, K. (2019). An Estimation of Working Capital Management on Profit Using Logistic Regression and Discriminant Analysis. Journal of Economics, Management and Trade 23(4): 1-9.

Dary, S. K., \& James, H. S. (2019). Does investment in trade credit matter for profitability? Evidence from publicly listed 
agro food firms. Research in International Business and Finance, 47, 237-250. https://doi.org/10.1016/j.ribaf.2018.07.012

Dodoo, R., Donkor, D.T. and Appiah, M. (2021). Examining the Factors that Influence Firm Performance in Ghana: A GMM And OLS Approach. Journal of Accounting and Management, 11(1), 83- 95.

Donkor, J. (2015). Working Capital Management of SMEs: Ghana's version of the story. Journal of Economics, Management and Trade, 1-12.

Evci, S., \& Şak, N. (2018). The Effect of Working Capital Management on Profitability in Emerging Countries: Evidence from Turkey. Financial Management from an Emerging Market Perspective, 205-218. http://dx.doi.org/10.5772/intechopen.70871.

Fiador, V. (2016). Does corporate governance influence the efficiency of working capital management of listed firms: Evidence from Ghana. African Journal of Economic and Management Studies, 7(4), 482-496. https://doi.org/10.

Frimpong, S. (2018). Working capital policies and value creation of listed non-financial firms in Ghana: a panel FMOLS analysis. Business and Economic Horizons, 4, 725-742.

Gachira, W., Chiwanzwa, W., Nkomo, D. J., \& Chikore, R. (2014). Working Capital Management and the Profitability of Non-Financial Firms Listed on the Zimbabwe Stock Exchange (ZSE). European Journal of Business and Economics, 9(2), 12-15.

Garcia-Teruel, J.P., \& Martinez-Solano, P. (2007). Effects of working capital management on SME profitability. International Journal of Managerial Finance, 3(2), 164-177.

Gujarati, D. N. (2004). Basic Econometrics (4th ed.). Tata, McGrawHill.

Hair, J. F., Black, W. C., Babin, B. J., Anderson, R. E., \& Tatham, R. L. (2016). Multivariate data analysis. Essex, England.

Hamza, K. Mutala, Z. and Antwi, S. K. (2015). Cash management practices and financial performance of small and medium enterprises (SMEs) in the northern region of Ghana. International Journal of Economics, Commerce and Management. 3(7), 456-480. https://doi.org/10.21276/sjbms

Hussain, S., Nguyen, V. C., Nguyen, Q. M., Nguyen, H. T., \& Nguyen, T. T. (2021). Macroeconomic factors, working capital management, and firm performance-A static and dynamic panel analysis. Humanities and Social Science Communications, 8:123 | https://doi.org/10.1057/s41599-021-00778-x.

Isshaq, Z. and Bokpin, G. A. (2009). Corporate liquidity management of listed firms in Ghana, Asia-Pacific Journal of Business Administration, 1(2) 189-198. https://doi.org/10.1108/17574320910989122

Kasahun, A. K. (2020). The Impact of Working Capital Management on Firms' Profitability Case of Selected Sole Proprietorship Manufacturing Firms in Adama City. Journal of Economics and Finance, 11(1), 45-55.

Kasozi, J. (2017). The effect of working capital management on profitability: a case of listed manufacturing firms in South Africa. Investment Management and Financial Innovations, 14(2), 336- 346.

Kennedy, P. (1998). A guide to econometrics (4th ed.). The MIT Press.

Kodithuwakku, S. (2015). Impact of Working Capital Management on Profitability: A Study on Listed Manufacturing Companies in Colombo Stock Exchange. Proceedings of 12th International Conference on Business Management (pp. 1-13). Colombo: SSRN.

Korankye, T., \& Adarquah, S. R. (2013). Empirical analysis of working capital management and its impact on the profitability of listed manufacturing firms in Ghana. Research Journal of Finance and Accounting, 4(1), 124131.

Korent, D., \& Orsag, S. (2018). The impact of working capital management on profitability of Croatian software companies. Zagreb International Review of Economics \& Business, 21(1), 47-65.

Liaqat, I., Khan, M.A., Popp, J. and Oláh, J. (2021). Industry, Firm, and Country Level Dynamics of Capital Structure: A Case of Pakistani Firms. Journal of Risk and Financial Management 14, 428. https:// doi.org/10.3390/jrfm140904

Lamptey, L. L., Frimpong, K., \& Morrison, A. B. (2017). Empirical study on the Influence of Working Capital Management on Performance of SMEs in a Developing Economy. Journal of Economics, Management and Trade, 217(4), 1-10.

Lamptey, J., Marsidi, A.B., Bilyaminu, U., and Ali, A.B. (2020). Overconfidence Behavioral Bias in Working Capital Management and Performance of Small and Medium Enterprise in Ghana: A Conceptual Paper. Malaysian Journal of Social Sciences and Humanities (MJSSH), 5(7), 124 - 129.

Lazaridis, I. and Tryfonidis, D. (2006). Relationship between working capital management and profitability of listed companies in the Athens stock exchange. Journal of Financial Management and Analysis, 19(1), 26-35.

Makori, D. M., \& Jagongo, A. (2013). Working capital management and firm profitability: Empirical evidence from manufacturing and construction firms listed on Nairobi Securities Exchange, Kenya. International Journal of Accounting and Taxation, 1(1), 1-14.

Mathuva, D. (2010). The influence of working capital management components on corporate profitability: A survey on Kenyan listed firms. Research Journal of Business Management, 4(1), 1-11.

Mazzarol, T. and Reboud, S. (2020). Cash flow, profit and working capital. In: Small business management. Springer Texts in Business and Economics. Springer, Singapore. https://doi.org/10.1007/978-981-13-9509-3 11

Matemilola B.T., Bany-Ariffin, A.N., Azman Saini, W.N.W., and Annuar Md, N. (2019). Impact ofinstitutional quality on the capital structure of firms in developing countries. Emerging Markets Review, 39, 175-209.

Mielcarz, P., Osiichuk, D., \& Wnuczak, P. (2018). Working capital management through the business cycle: Evidence 
from the corporate sector in Poland. Contemporary Economics, 12(2), $223-236$. https://doi.org/10.5709/ce.1897-9254.273.

Mohammed, N.E.A.B. and Saad, N.B.M. (2010). Working Capital Management: The Effect of Market Valuation and Profitability in Malaysia. International Journal of Business and Management, 5(11), 140-147. DOI: 10.5539/ijbm.v5n11p140.

Mwangi, L.W., Makau, M.S. and Kosimbei, G. (2014). Effects of Working Capital Management on Performance of NonFinancial Companies Listed In NSE, Kenya. European Journal of Business and Management 6(11), 195-205.

Musa, A.B., Matemilola, B.T. and Bany-Ariffin, A.N. (2021). Impact of Non-Financial Firms Capital Structure on Firm -Value Performance in Developing Africa. International Journal of Management, 12(1), 1483-1491. http://www.iaeme.com/IJM/issues.asp?JType=IJMandVType=12andIType=1

Nazir, M. S., \& Afza, T. (2009). Impact of Aggressive Working Capital Management Policy on Firms' Profitability. The IUP Journal of Applied Finance, 15(8), 19-30.

Ng, C.K., Smith, J.K., \& Smith, R.L. (1999). Evidence on the determinants of credit terms used in interfirm $t$ rade. Journal of Finance, 54(3), 1109-1129.

Nguyen, A. H., Pham, H. T., \& Nguyen, H. T. (2020). Impact of Working Capital Management on Firm's Profitability: Empirical Evidence from Vietnam. The Journal of Asian Finance, Economics, and Business, 7(3), 115-125.

Nikkinen, J., Graham, M., \& Enqvist, J. (2014). The impact of working capital management on firm profitability in different business cycles: Evidence from Finland. Research in International Business and Finance, 32, 36-49.

Nyeadi, J.D., Sare, Y.A. \& Aawaar, G. (2018). Determinants of working capital requirement in listed firms: Empirical evidence using a dynamic system GMM. Cogent Economics \& Finance, 6(1), DOI: $10.1080 / 23322039.2018 .1558713$

Obeng, H., Enos, B.K., Yensu, J. (2021). Working capital management, working capital policy, and firm performance in Ghana: empirical evidence using a dynamic system GMM.

African Journal of Business and Economic Research, 16(1). https://doi.org/10.31920/1750$4562 / 2021 / \mathrm{v} 16 \mathrm{n} 1 \mathrm{a} 11$.

Ofoeda, I (2017). Corporate governance and non-bank financial institutions profitability. International Journal of Law and Management, 59 (6), 854-875. https://doi.org/10.1108/ IJLMA-05-2016-0052.

Ogundipe, S.E., Idowu, A. and Ogundipe, L.O. (2012). Working Capital Management, Firms’ Performance and Market Valuation in Nigeria. World Academy and Science, Engineering and Technology, 61, 1196-1200.

Onwumere, J.U.J., Ibe, I.G. and Ugbam, O.C. (2012). The Impact of Working Capital Management on Profitability of Nigerian Firms: A Preliminary Investigation. European Journal of Business and Management, 4(15), $192-201$.

Othuon, D.O., Gatimbu, K.K., Musafiri, C.M. and Ngetich, F.K. (2021). Working capital management impacts on small-scale coffee wet mills' financial performance in eastern Kenya. Heliyon 7, 1-9. https://doi.org/10.1016/j.heliyon.2021.e07887.

Owolabi, U. and Halimah, N. (2021). Analysis of the Effect of Working Capital Components and Profitability of Selected Quoted Manufacturing Firms in Nigeria. Journal of Applied Mathematics and Statistical Analysis, 2(2),

Peng, J. and Zhou, Z. (2019). Working Capital Optimization in a Supply Chain Perspective (2019). European Journal of Operational Research, 277 (3), 846-856

Peprah, W.K., Anowuo, I. and Ameyaw, D.A.K. (2019). The Relationship between Working Capital Management and Financial Sustainability of Selected Christian Denominations in Ghana. Applied Finance and Accounting, 5(2), 2374-2429.

Peprah, W.K. \& Riziki, A. (2019). The relationship between working capital and profitability: A confirmatory study from selected banks in Ghana. $1^{\text {st }}$ International Research Forum. On Fire: Excellence in Research, Putting Kahoy, Silang, Cavite, Philippines.

Phuong, N., \& Hung, D. (2020). Impact of working capital management on firm profitability: Empirical study in Vietnam. Accounting, 6(3), 259-266.

Pirashanthini, S., Tharmila, K., and Velnampy, T., 2013. Working Capital Approaches and Firm's Profitability of Manufacturing Companies in Sri Lanka. Comprehensive Research Journal of Management and Business Studies, 1(2), 24-30.

Ponsian, N., Chrispina, K., Tago, G., \& Mkiibi, H. (2014). The effect of working capital management on profitability. International Journal of Economics, Finance and Management Sciences, 2(6), 347-355. doi: $10.11648 /$ j.ijefm.20140206.17.

Prempeh, K.B., and Peprah-Aamakona, G. (2019). Does Working Capital Management Affect Profitability of Ghanaian Manufacturing Firms? Journal of Advanced Studies in Finance, 19, 22-33

Prempeh, K. B. (2016). The Impact of Efficient Inventory Management on Profitability: Evidence from Selected Manufacturing Firms in Ghana. International Journal of Finance and Accounting, 5(1), 22-26. DOI: 10.5923/j.ijfa.20160501.03.

Qurashi, M., \& Zahoor, M. (2017). Working capital determinants for the UK pharmaceutical companies listed on the FTSE 350 Index. International Journal for Academic Research in Accounting, Finance and Management Sciences, 7(1), 11-17.

Rahman, S., Iqbal, K., \& Nadeem, A. (2019). Effect of Working Capital Management on Firm Performance: The Role of Ownership Structure. Global Social Sciences Review, 4(1), 108-119.

Ray, S. (2012). Evaluating the Impact of Working Capital Management Components on Corporate Profitability: Evidence 
from Indian Manufacturing Firms. International Journal of Economic Practices and Theories, 2(3), 127-136.

Ross, S. A., Westerfield, R. W. and Jaffe, J. (2016). Corporate Finance. Irwin / McGraw-Hill, $11^{\text {th }}$ Edition, Maidenhead.

Sargan, J. D. (1958). The instability of the Leontief dynamic model. The Econometric Society, 26(3), 381-392.

Sattar, A. R. (2019). Does working capital management play mediating role? Determinants of capital structure. European Online Journal of Natural and Social Sciences, 8(2), 309-315.

Senan, N.A.M., Anagreh, S., B.O.A., Al-dalaien, Almugari, F., Khaled, A.S.D. and Al-homaidi, E.A. (2021). Working Capital Management and Banks' Performance: Evidence from India. Journal of Asian Finance, Economics and Business, 8 (6), 0747-0758.

Tauringana, V., \& Afrifa, G.A. (2013). The relative importance of working capital management and its components to SMEs' profitability. Journal of Small Business and Enterprise Development, 20(3), 453-469. https://doi.org/10.1108/JSBED-12-2011-0029.

Tsagem, M.M. (2020). Cash conversion cycle and profitability of Nigerian small and medium-sized entities: an empirical analysis. International journal Banking and Finance. 13(1), 49-69. https://doi.org/10.11648/j.jfa.20160406.15

Ukaebe, B. (2014). The significance of working capital management in determining firm profitability: Evidence from developing economies in Africa. Research in International Business and Finance, 31, 1-6. http://dx.doi.org/10.1016/j.ribaf.2013.11.005.

Wilner, B.S. (2000). The exploitation of relationships in financial distress: The case of trade credit. Journal of Finance, $55(1), 153-178$.

Wooldridge, J. M. (2001). Applications of Generalized Method of Moments Estimation. Journal of Economic Perspectives, 15(4), 87-100.

Yakubu, I.N. (2021). The Effect of Working Capital Management on Dividend Policy: An Empirical Analysis of Listed Firms in Ghana. International Journal of Industrial Management, 9(1), 25-31.

Yakubu I.N., Kapusuzoglu A., Ceylan N.B. (2020). Determinants of Working Capital Management of Manufacturing Firms in Ghana Under Innovative Work Behaviour Perspective. In: Dincer H., Yüksel S. (eds) Strategic Outlook for Innovative Work Behaviours. Contributions to Management Science. Springer, Cham. https://doi.org/10.1007/978-330-50131-0_14.

Yakubu, I. N., Alhassan, M. M., \& Fuseini, A. A. (2017). The Impact of Working Capital Management on Corporate Performance: Evidence from Listed Non-Financial Firms in Ghana. European Journal of Accounting, Auditing and Finance Research, 5(3), 68-75.

Yazdanfar, D., \& Öhman, P. (2016). The impact of trade credit use on firm profitability: Empirical evidence from Sweden. Journal of Advances in Management Research, 13(2), 1-16. http://doi.org/10.1108/JAMR-09-2015-0067.

Yeboah, B. and Kwaku Agyei, S. (2012). Working Capital Management and Cash Holdings of Banks in Ghana. European Journal of Business and Management, 4(13)

Windmeijer, F. (2005). A finite sample correction for the variance of linear efficient two-step GMM estimators. Journal of Economics, 126(1), 25-51. https://doi.org/10.1016/j.jeconom.

\section{ACKNOWLEDGEMENT}

The authors would like to thank the editor and anonymous referees for their insightful review and inputs that has greatly enrich this empirical inquiry.

\section{DECLARATION CONFLICT OF INTEREST}

The authors declare that there is no conflict of interests. 


\section{AUTHORS' BIOGRAPHY}

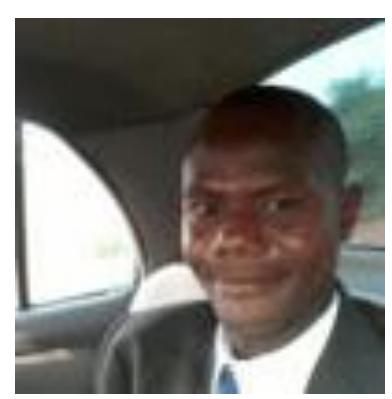

Author's Full Name: Ronald Ebenezer Essel

Author's Email: esselronald@yahoo.com

Author's Professional Bio:

Ronald Ebenezer Essel is a Tutor in Finance at the University of Cape Coast, College of Distance Education, Unit of Business programmes, Ghana. He holds M.Phil and B.Sc.(Admin) finance degrees, from the University of Ghana Business School. Ronald was a Credit Analyst at Republic Bank and Prudential Bank for six years. He also worked with theSOFTtribe Limited for a year as a software implementation/support officer. Ronald's research interest is in finance/economics: financial markets developments; FDI \& growth; corporate governance, TQM, service quality, supply chain management \& corporate performance; banking \& international trade; gender-based violence issues in Africa and has published widely in recognized academic/scholarly/peer-review/referred journals. Ronald has undertaken a number of research-based-consultancy services with sponsorship/funding from international donors-STAR Ghana-DANIDAUKAID/DFIS-European Union and as a result, gained enormous technical abilities/skills in the design/application of results-based-business/social research, familiarity with qualitative/quantitative research methodologies, with sharpened capacities working with NGOs, CSOs, MMDAs and international organizations.

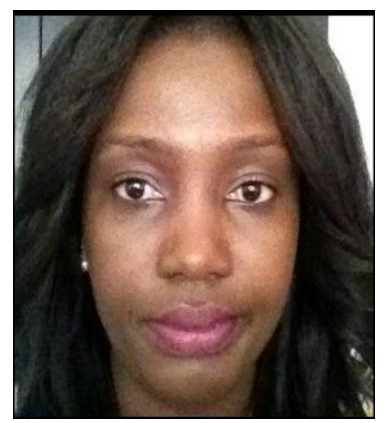

Author's Full Name: Joyce Akua Brobbey

Author's Email: bakuajoyce@gmail.com

Author's Professional Bio:

Joyce Akua Brobbey is the current Coordinator of Odorgonno SHS Study Centre and a Tutor in Accounting at the University of Cape Coast (UCC), College of Distance Education (CoDE), Unit of Business programmes, Ghana. She holds ACCA (UK) professional certificate and a B.A. (Hons) economics with Psychology, from the University of Ghana, Legon, Accra, Ghana. Ms. Brobbey has extensive professional corporate/industry experience in accounting related environments, having worked as Account Manager with international reputable institutions like Ashford Louis Accountants (UK), Joyce Darfoor Limited (UK) among other international accounting firms. Her research area is in accounting and auditing with specialty in advance corporate financial reporting and auding. 